\title{
Current Biology \\ Early Alpine occupation backdates westward human migration in Late Glacial Europe
}

\section{Highlights}

- Genetic replacement in Southern European hunter-gatherers started at least $17 \mathrm{ka}$ ago

- The shift follows the LGM and precedes the onset of the Bølling/Allerød event

- This process is chronologically associated with major cultural transitions in Europe

\section{Authors}

Eugenio Bortolini, Luca Pagani, Gregorio Oxilia, ..., Sahra Talamo, Maurizio D'Esposito, Stefano Benazzi

\section{Correspondence}

eugenio.bortolini2@unibo.it (E.B.), luca.pagani@unipd.it (L.P.), gregorio.oxilia3@unibo.it (G.O.)

\section{In brief}

Bortolini et al. generate genomic evidence and direct dating from an individual who lived $\sim 17 \mathrm{ka}$ ago in northeastern Italy and backdate by about $3 \mathrm{ka}$ the diffusion in Southern Europe of a genetic component linked to Balkan/ Anatolian refugia previously believed to have spread during later major warming shifts. 


\title{
Early Alpine occupation backdates westward human migration in Late Glacial Europe
}

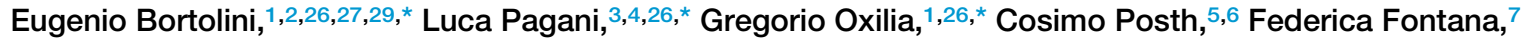 \\ Federica Badino, ${ }^{1,8}$ Tina Saupe, ${ }^{4}$ Francesco Montinaro, ${ }^{4}$ Davide Margaritora, ${ }^{7}$ Matteo Romandini, ${ }^{1}$ Federico Lugli, ${ }^{1}$ \\ Andrea Papini, ${ }^{9}$ Marco Boggioni, ${ }^{10}$ Nicola Perrini, ${ }^{11}$ Antonio Oxilia, ${ }^{12}$ Riccardo Aiese Cigliano, ${ }^{13}$ Rosa Barcelona, ${ }^{13,14,15}$ \\ Davide Visentin, ${ }^{16}$ Nicolò Fasser, ${ }^{7}$ Simona Arrighi, ${ }^{1}$ Carla Figus, ${ }^{1}$ Giulia Marciani, ${ }^{1}$ Sara Silvestrini, ${ }^{1}$
}

(Author list continued on next page)

\author{
${ }^{1}$ Department of Cultural Heritage, University of Bologna, Via degli Ariani, 148121 Ravenna, Italy \\ ${ }^{2}$ CaSEs (Culture and Socio-Ecological Dynamics) Department of Humanities, Universitat Pompeu Fabra, Ramon Trias Fargas, 25-27, 08005 \\ Barcelona, Spain \\ ${ }^{3}$ Department of Biology, University of Padova, Viale G. Colombo 3, 35131 Padova, Italy \\ ${ }^{4}$ Estonian Biocentre, Institute of Genomics, University of Tartu, Riia 23b 51010 Tartu, Estonia \\ ${ }^{5}$ Department of Archaeogenetics, Max Planck Institute for the Science of Human History, Jena 07745, Germany \\ 6Institute for Archaeological Sciences, Archaeo- and Palaeogenetics, University of Tübingen, Rümelinstrasse 19-23, 72070 Tübingen, \\ Germany \\ ${ }^{7}$ Department of Humanities - Section of Prehistoric and Anthropological Sciences, University of Ferrara, Corso Ercole I d'Este 32,44121 \\ Ferrara, Italy \\ ${ }^{8}$ Research Group on Vegetation, Climate and Human Stratigraphy, Lab of Palynology and Palaeoecology, CNR - Institute of Environmental \\ Geology and Geoengineering (IGAG), 20126 Milano, Italy \\ 9Dentist surgeon, via Walter Tobagi 35, 59100 Prato, Italy \\ ${ }^{10}$ Dentist surgeon, via D'Andrade 34/207, 16154 Genova Sestri Ponente, Italy \\ ${ }^{11}$ Dentist surgeon, Centro di Odontoiatria e Stomatologia, Via Luca Signorelli, 5, 51100 Pistoia PT, Italy \\ ${ }^{12}$ General surgeon, via Marcantonio Della Torre, 7, 37131 Verona, Italy \\ ${ }^{13}$ Sequentia Biotech, Calle Comte D’Urgell 240, 08036 Barcelona, Spain \\ ${ }^{14}$ Institute of Genetics and Biophysics “Adriano Buzzati-Traverso," National Research Council of Italy, Via P.Castellino 111, 80131 Naples, \\ Italy
}

(Affiliations continued on next page)

\section{SUMMARY}

Before the end of the Last Glacial Maximum (LGM, 16.5 ka ago) $)^{1}$ set in motion major shifts in human culture and population structure, ${ }^{2}$ a consistent change in lithic technology, material culture, settlement pattern, and adaptive strategies is recorded in Southern Europe at $\sim 18-17 \mathrm{ka}$ ago. In this time frame, the landscape of Northeastern Italy changed considerably, and the retreat of glaciers allowed hunter-gatherers to gradually recolonize the Alps. ${ }^{3-6}$ Change within this renewed cultural frame (i.e., during the Late Epigravettian phase) is currently associated with migrations favored by warmer climate linked to the Bølling-Allerød onset (14.7 ka ago), ${ }^{7-11}$ which replaced earlier genetic lineages with ancestry found in an individual who lived $\sim 14 \mathrm{ka}$ ago at Riparo Villabruna, Italy, and shared among different contexts (Villabruna Cluster). ${ }^{9}$ Nevertheless, these dynamics and their chronology are still far from being disentangled due to fragmentary evidence for long-distance interactions across Europe..$^{12}$ Here, we generate new genomic data from a human mandible uncovered at Riparo Tagliente (Veneto, Italy), which we directly dated to $16,980-16,510$ cal BP $(2 \sigma)$. This individual, affected by focal osseous dysplasia, is genetically affine to the Villabruna Cluster. Our results therefore backdate by at least $3 \mathrm{ka}$ the diffusion in Southern Europe of a genetic component linked to Balkan/Anatolian refugia, previously believed to have spread during the later Bølling/Allerød event. In light of the new genetic evidence, this population replacement chronologically coincides with the very emergence of major cultural transitions in Southern and Western Europe.

\section{RESULTS AND DISCUSSION}

Riparo Tagliente represents the earliest available evidence of human occupation of the southern Alpine slope ${ }^{5}$ while the major glaciers in the area started withdrawing at 17.7-17.3 cal BP $(2 \sigma)^{6,13}$ and is therefore critical to address questions on the impact of human movement in this time frame (Figure 1; STAR Methods). We performed anthropological (STAR Methods, Method details) and genetic analyses to assess the biological background of the sampled individual. The hemimandible, which is affected by focal cemento-osseous dysplasia (Figures 2 and S1; STAR Methods, Method details), was also directly dated 


\title{
Current Biology Report
}

\author{
Federico Bernardini, ${ }^{17,18}$ Jessica C. Menghi Sartorio, ${ }^{7}$ Luca Fiorenza, ${ }^{19,20}$ Jacopo Moggi Cecchi, ${ }^{21}$ Claudio Tuniz, ${ }^{18,22}$ \\ Toomas Kivisild, ${ }^{4,23}$ Fernando Gianfrancesco, ${ }^{14}$ Marco Peresani, ${ }^{7}$ Christiana L. Scheib, ${ }^{4}$ Sahra Talamo, ${ }^{24,25}$ \\ Maurizio D'Esposito, ${ }^{14,28}$ and Stefano Benazzi ${ }^{1,25}$ \\ ${ }^{15}$ Departamento de Matemáticas, Escuela Técnica Superior de Ingeniería Industrial de Barcelona (ETSEIB), Universitat Politècnica de \\ Catalunya (UPC), Diagonal 647, 08028 Barcelona, Spain \\ ${ }^{16}$ Archaeology of Social Dynamics, Institució Milà i Fontanals, Spanish National Research Council (IMF-CSIC), C/Egipcíaques 15, 08001 \\ Barcelona, Spain \\ ${ }^{17}$ Department of Humanities, Università Ca' Foscari Venezia, Dorsoduro, 3484/D, 30123 Venezia, Italy \\ ${ }_{18}^{18}$ Multidisciplinary Laboratory, The "Abdus Salam" International Centre for Theoretical Physics (ICTP), Strada Costiera, 11 - 34151 Trieste, \\ Italy \\ ${ }^{19}$ Monash Biomedicine Discovery Institute, Department of Anatomy and Developmental Biology, Monash University, Melbourne, VIC 3800, \\ Australia \\ ${ }^{20}$ Earth Sciences, University of New England, Armidale, NSW 2351, Australia \\ ${ }^{21}$ Department of Biology, University of Florence, Via del Proconsolo, 12, Firenze 50122, Italy \\ ${ }^{22}$ Centre for Archaeological Science, University of Wollongong, Northfields Avenue, Wollongong, NSW 2522, Australia \\ ${ }^{23}$ Department of Human Genetics, KU Leuven, Leuven 3000, Belgium \\ ${ }^{24}$ Department of Chemistry "G. Ciamician," University of Bologna, Via Selmi, 2, 40126 Bologna, Italy \\ ${ }^{25}$ Max Planck Institute for Evolutionary Anthropology, Department of Human Evolution, Deutscher Platz 6, 04103 Leipzig, Germany \\ 26These authors contributed equally \\ 27Twitter: @erc_success \\ ${ }^{28}$ Deceased \\ ${ }^{29}$ Lead contact \\ *Correspondence: eugenio.bortolini2@unibo.it (E.B.), luca.pagani@unipd.it (L.P.), gregorio.oxilia3@unibo.it (G.O.) \\ https://doi.org/10.1016/j.cub.2021.03.078
}

to independently ascertain its chronology and the possible contemporaneity with contextual, post-cranial human remains from a partially preserved burial (Tagliente1; STAR Methods). ${ }^{14,15}$ The root of the first molar $\left(\mathrm{LM}_{1}\right)$ from the hemimandible of Tagliente2 was directly dated to $16,980-16,510$ cal BP $\left(95.4 \%\right.$ probability using IntCal $20^{16}$ in OxCal v.4.3; ${ }^{17}$ Data S1A), confirming the attribution to the Late Epigravettian chronological range, i.e., the same cultural context as Tagliente1 $\left(16,130-15,560\right.$ cal BP; $2 \sigma$ range obtained using Reimer et al.; ${ }^{16}$ Data S1A; STAR Methods, Method details).

We extracted DNA from five samples taken from mandibular and tooth tissues and screened for the presence of endogenous human DNA through a pooled whole-genome sequencing. One of the healthy mandibular samples yielded sufficient endogenous DNA (5.06\%) and was re-sequenced to achieve a total genome-wide coverage of $0.28 \times$, yielding $266 \mathrm{~K}$ SNPs overlapping with the $1240 \mathrm{~K}$ Human Origins SNP Array. We also provide a number of missense variants found to overlap with genes known to be involved with cementoma insurgence, which, given low coverage and ancient DNA degradation, are reported with no further interpretation (Data S1B; STAR Methods, Method details). Overall contamination estimated from mtDNA was $2.158 \%$ and $0.60 \%-1.53 \%$ from the $X$ chromosome (Data $\mathrm{S} 1 \mathrm{C}$ ). The mtDNA haplogroup is a basal U2'3'4'7'8'9 (Data S1C and S1D), consistent with a European Palaeolithic individual (Figure $3 \mathrm{~A})$, also shared by Rigney 1 (15.5 ky cal BP) ${ }^{9}$ and Paglicci Accesso Sala 2 Rim P ( 13 ka ago). ${ }^{24}$ X/autosome coverage ratio in the order of 0.56 suggests the individual was male, in accordance with results of morphological analysis (STAR Methods, Method details), and the chromosome $Y$ haplogroup was estimated to be 12, which captures the majority of diversity in Europe after $\sim 14$ ka ago (Figure 3B; Data S1E). Most samples dated to this period fall within a single mtDNA (U5b) ${ }^{10}$ and chrY (I2) ${ }^{9}$ branch, flagging a putative expansion from a single founding population.
From a population perspective, we performed a multi-dimensional scaling (MDS) analysis based on outgroup f3 distances (Figure 4A) and found the sample to fall within the broader European Western Hunter-Gatherer (WHG) genetic variation, pointing to an affinity to the previously described Villabruna Cluster. This group has been defined on the basis of genetic affinity among individuals known to have largely replaced previous European Hunter-Gatherer populations at least $\sim 14 \mathrm{ka}$ ago. Notably, these individuals showed little or no trace of genetic contributions from pre-existing European groups, such as the ones genetically close to the Dolní Věstonice or to Goyet-Q116-1 human remains and known to have inhabited Europe until the LGM. ${ }^{9}$ One of the defining features of the Villabruna Cluster is a higher affinity with Near Eastern genetic components than that exhibited by pre-existing Palaeolithic West Eurasians. The significantly negative $\mathrm{f} 4$ test (Kostenki14, Tagliente2, Druze, Mbuti: $\mathrm{f} 4=-0.0037$; standard error $=0.00063 ; Z=-5.88$ ) further confirmed Tagliente2 to share genetic features with the Villabruna Cluster and to be in discontinuity with the preceding European genetic background. We followed up this observation using a series of $\mathrm{f} 4$ tests in the form Tagliente2, $\mathrm{X} ; \mathrm{Y}, \mathrm{Mbuti}$, where $\mathrm{Y}$ is a population of interest and $X$ is either Villabruna $\left(\sim 14\right.$ ka ago), ${ }^{9}$ Bichon $(\sim 13.7 \mathrm{ka}$ ago), ${ }^{9}$ or a Mesolithic Italian from Grotta Continenza ( 11.9 ka ago; Figure 4B). ${ }^{26}$ We chose three independent WHG samples to control for potential biases introduced by the genotyping strategy and indeed found small discrepancies when we compared results obtained using capture (Villabruna) or shotgun (Bichon and Continenza) data. To minimize this effect, we chose to put more weight on the interpretation of shotgun results, deemed to be more readily comparable with the shotgun data generated for Tagliente2 in this study. We also show that the data available are sufficient to achieve significance in a f4 test when the order of $X$ and $Y$ populations are inverted, as for Tagliente, $Y$, Grotta Continenza, Mbuti (Figure S2). The higher affinity of Continenza and Bichon to later WHG (Loschbour, Iberia_HG and Continenza, 


\section{Current Biology}

\section{Report}
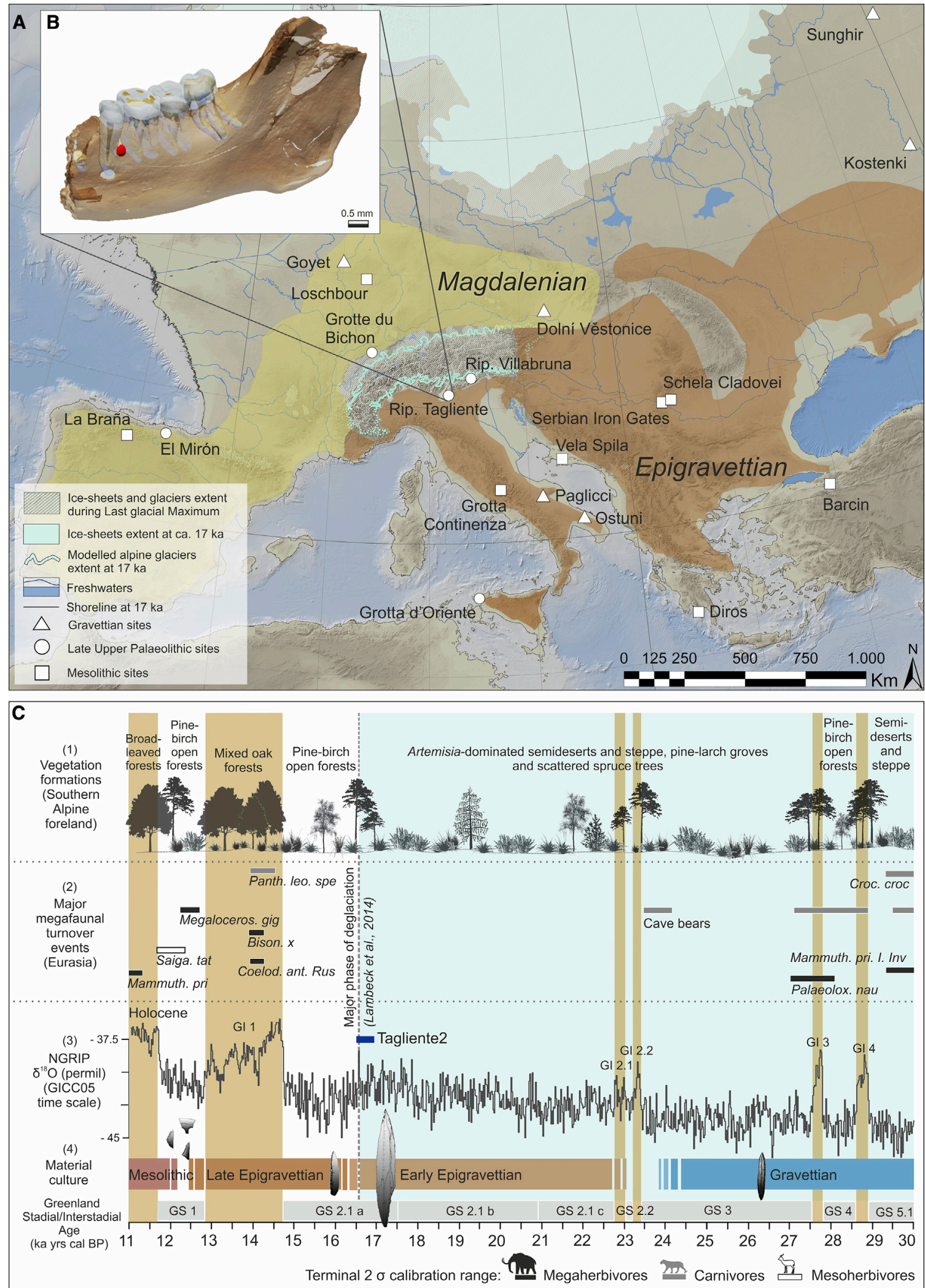


\section{$\infty$ CellPress}
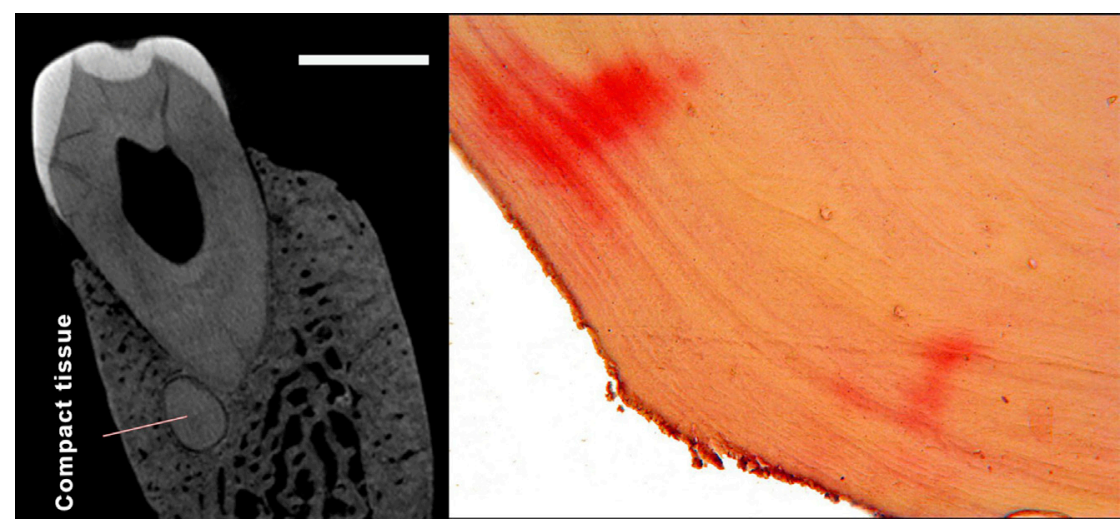

Bichon, and Villabruna themselves) when compared to Tagliente2 may be explained by the more ancient age of Tagliente2 or with the former individuals being genetically closer to the ancestry that reached central Europe at least by $14 \mathrm{ka}$ ago. Alternatively, the higher affinity emerging among more recent WHG samples may also be ascribed to subsequent admixtures between the newly arrived Tagliente2 individuals and pre-existing Dolní Věstonice- or Goyet Q116-1-like ( 35 ka ago $)^{9}$ genetic substrates, as already reported for Loschbour ( 8.1 ka ago). ${ }^{9,27} \mathrm{We}$ then modeled the position of Tagliente 2 within the tree proposed by Fu and colleagues ${ }^{9}$ (Figure S3A) and found that it may fit well within the Villabruna branch, confirming previous results (Figures S3B-S3D). To minimize the effects of the mismatch between capture and shotgun data due to attraction, we also explore the feasibility of the basic qpGraph (Figure S3B) using, where possible, shotgun samples (Figure S4).

With our work, we provide genomic, uniparental, and chronological evidence that backdates the presence of the so called Villabruna component in Northern Italy to as early as $17 \mathrm{ka}$ ago, when it chronologically overlaps with major cultural transitions involving the region. The shift from Early to Late Epigravettian has not been abrupt, and despite the emergence of regionalism and environmental/cultural differences between Adriatic and Tyrrhenian contexts, ${ }^{12}$ change in the relative frequency of artifact types and reduction sequences, as well as in raw material procurement and settlement patterns, can be recorded since $\sim 17$ ky cal BP. ${ }^{4,5,12,28-34}$ After 14 ky cal BP, a more-marked discontinuity is attested by the greater reliance on geometric microlithic pieces and a stronger presence of engraved and painted bones and stones bearing linear, geometric, zoomorphic, or anthropomorphic motives. ${ }^{28,30,34}$

The Early to Late Epigravettian transition is broadly coeval to a marked retreat of Alpine glaciers (ca. 18-17.5 ka ago ${ }^{35}$ after they

\section{Current Biology} Report

Figure 2. Tagliente2 virtual (left) and physical (right) section

On the left, microCT distal view of the premolar and its pathological cementum tissue. On the right, histological section is shown. Magnification (250x) of the cementum tissue colored by hematoxylin/ eosin. B, buccal; L, lingual; scale bar represents $0.5 \mathrm{~mm}$ (see Figure S1, Data S1B, and STAR Methods).

had reached their maximum between 26 and $24 \mathrm{ka} \mathrm{ago}^{13}$ and to a rapid rise in sea levels since $16.5 \mathrm{ka}$ ago. ${ }^{1}$ These processes led to considerable change in the geomorphology of the Alpine sectors and stabilized large surfaces of the Great Adriatic/Po Region. ${ }^{12}$ A rapid forest recolonization of the Alpine foothills started about $17 \mathrm{ka}$ cal BP, well before the major Bølling/Allerød warmup. 6,36,37 Alpine forelands became (open) pine forests with tree Betula and Larix (Figure 1C) ${ }^{3}$ while open vegetations developed in the distal sector of the megafans. ${ }^{12,38}$ At the end of LGM, local faunal availability was limited and mostly consisted of species adapted to open environments that had been able to find their climatic optimum by moving to higher elevations in warmer interstadials (e.g., Alpine ibex and marmot) or taking refuge (e.g., elk) in areas with favorable microclimates. Most Central European, cold-adapted megafaunal species had entered northern Italy before the onset of LGM through the central Slovenian corridor-the same used by Gravettian huntergatherers to follow game and settle across the Adriatic. ${ }^{12}$ During LGM, both new arrivals and northward movements of these large mammals were hampered, and they either locally disappeared or became extinct in association with short LGM interstadials (as in the case of cave bears, between 24.2 and $23.5 \mathrm{ka}$ ago). ${ }^{21}$ The reduction of the forest cover during colder phases is confirmed by the presence of Capra ibex, Rupicapra rupicapra, and Marmota marmota, both in the core of the Po Plain and in caves and shelters of Berici Hills. ${ }^{39,40}$ In the same area, archaeological records show the presence of palaeoarctic birds ${ }^{41}$ currently only found in high-latitude regions of the northern hemisphere.

Taken together, our results support two different-although not mutually exclusive-scenarios. The first one involves a broad network of refugia connecting Mediterranean and Eastern Europe during and immediately after the LGM. The network could have facilitated long-distance transmission through a stepwise exchange of both cultural and genetic information from the Black Sea all the way to the Iberian Peninsula. This scenario, which cannot be tested with the available evidence, would predict a

Figure 1. Geographical, ecological, and cultural context of the study

(A) Palaeogeographic map of Europe during Late Glacial, centered at 17 ka ago (see Method details). Colored areas refer to the distribution of Epigravettian and Magdalenian material culture at $17 \mathrm{ka}$ ago, although white symbols indicate the geographic location of the main sampling sites discussed in the text ( $30-8 \mathrm{ka}$ ago).

(B) 3D lateral view of the hemimandible Tagliente2 with roots, pulp chambers, dentine, and enamel of the preserved teeth, as well as the cementome (in red) between the distal side of $\mathrm{P}_{3}$ root and the mesial root side of $\mathrm{M}_{1}$ (Figure $\mathrm{S} 1$ ).

(C) Comparison between palaeoclimate, palaeoenvironmental, and cultural proxies over the 30-11 ka cal BP time span. Key to panels is as follows: (1) reconstruction of Southern Alpine past vegetation; ${ }^{3,6,18,19,20}(2)$ Eurasian major megafaunal transitions (regionwide extirpations or global extinctions, or invasions, of species or major clades); ${ }^{21,22}$ (3) NGRIP $\delta^{18}$ O record in 20 years means on the GICC0 5 timescale; ${ }^{23}$ and (4) material cultural sequence for Eastern and Southern Europe. Chronology for Tagliente2 ( $2 \sigma$ obtained using Reimer et al. ${ }^{16}$; Data S1A) is marked in blue. 


\section{Current Biology \\ Report}

A

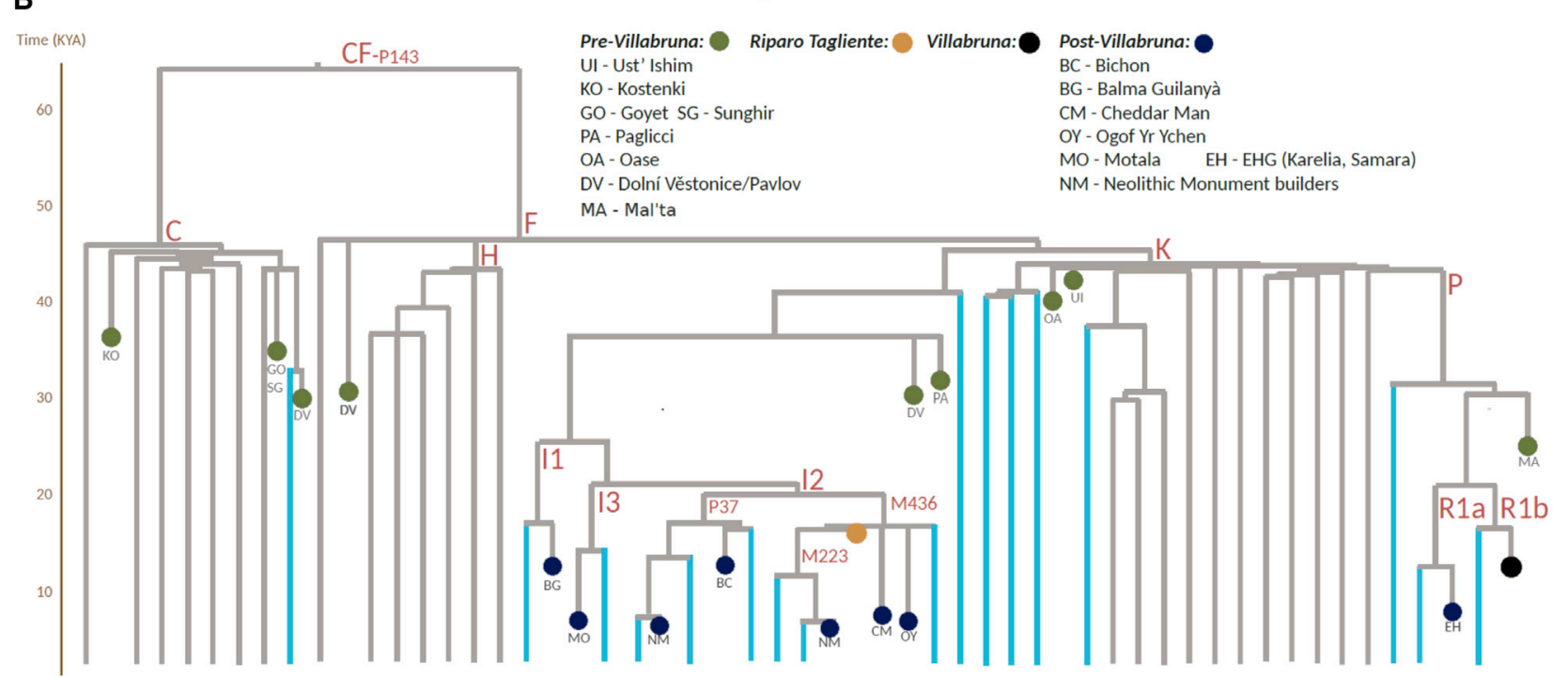

|l Lineages characteristic to present-day Europeans

Figure 3. Uniparental haplogroups of Tagliente2

(A) mtDNA haplogroup of Tagliente2 (in gold; Data S1C and S1D; Figure S4) within a number of pre-(green) and post (blue)-Villabruna samples.

(B) chrY haplogroup of Tagliente2 (gold; Data S1C and S1E) surrounded by post-Villabruna samples (including Bichon [BC]). Y haplogroup splits are drawn according to the dater estimates based on high-coverage modern sequences. ${ }^{25}$ The ancient individuals are mapped on this tree, considering the available haplogroup-informative available SNP data, and private mutations in the ancient samples have been ignored.

relationship between the age of a sample, its geographic location, and the relative abundance of Villabruna genetic components shared with present-day Near Easterners. From a cultural point of view, the development of Early and Late Epigravettian material culture in Southern Europe would not be directly driven by abrupt, millennial-scale climatic events and could result from convergence, local adaptation, and cultural diffusion without entailing population movement. In this case, geographic distance between sites would also predict similarity in lithic assemblages.

The second scenario implies instead population movement and replacement, a more-abrupt genetic turnover, and a distribution of both genetic and cultural similarities that is not well predicted by geographic clines. This population shift could have taken place during the LGM, i.e., after $\sim 27$ ka ago, when Věstonice-like components were still visible at Ostuni (Southern
Italy) and before $\sim 17 \mathrm{ka}$ ago. Groups bearing the Villabruna lineage may have exploited the Slovenian corridor and lower Adriatic Sea levels to occupy Adriatic Italy up to the Po plain and recolonized pre-Alpine valleys only at a later stage. According to this model, after $\sim 27 \mathrm{ka}$ ago, genetic lineages found in Italy and only later in France and Spain, should show either or both of (1) genomic affinities with the Villabruna Cluster and (2) uniparental lineages belonging to U2' 3'4'7'8'9/U5b mtDNA and/or I2/R1a $\mathrm{Y}$ groups. According to this model, cultural change recorded in Italy across the Epigravettian sequence may have been at least in part triggered by demic processes linked to population replacement.

From a cultural perspective, the biased spatial and temporal distribution of the available archaeological record can hardly be used to directly discriminate between these two models, 
A

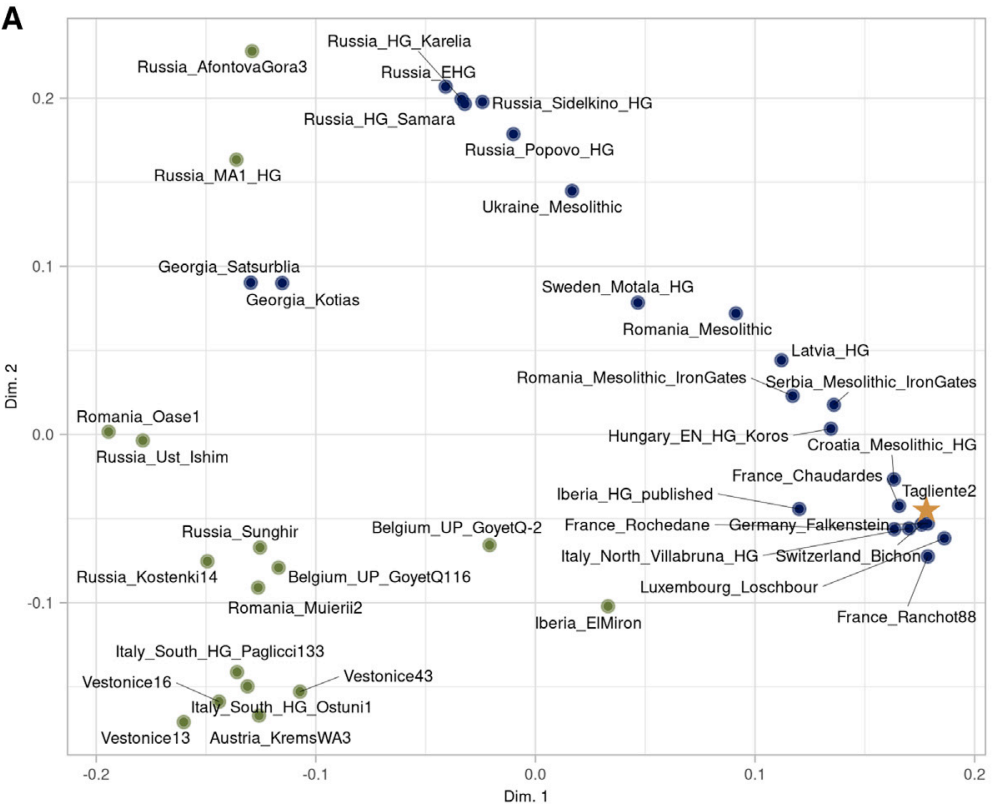

B

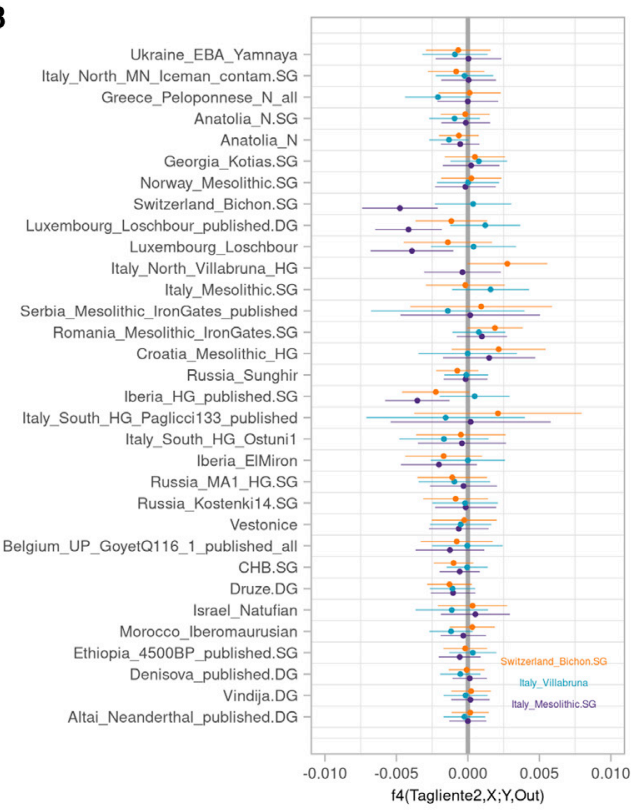

Figure 4. Demographic inference from Tagliente2

(A) Multi-dimensional scaling based on Mbuti; X, Tagliente2 outgroup f3 statistics show Tagliente2 (golden star) to cluster within the Villabruna Cluster (in blue) and away from the pre-existing South European samples (in green).

(B) f4 tests (Tagliente2, X, Y, Mbuti \pm 3 SE) where X is either a Mesolithic Italian, Villabruna, or BC WHG sample and Y, shown along the y axis, is a population of interest (Data S1C; Figures S2-S4).

and there is still considerable uncertainty on the temporal dynamics underlying the beginning of the Late Epigravettian across the whole of Italy. ${ }^{12}$ Since $\sim 18$ to 17 cal kBP, there is evidence of a shift from Solutrean to Magdalenian material culture in Southwestern Europe and from Early to Late Epigravettian material culture in a vast area ranging from the Rhone river to the Southern Russian plain. ${ }^{12,30,42,43}$ Environmental pressure conditioned the movement of megafauna during the LGM and limited the movement of human groups to corridors connecting Southern Europe, the Balkans, and Eastern Europe. In this period, human groups inhabiting Southern Europe were exposed to limited ecological risk compared to other regions of Central and Northern Europe. ${ }^{2,44-46}$ Variability in Sr isotope composition of individuals uncovered at Grotta Paglicci (Apulia, Southern Italy) shows a conspicuous change in residential mobility patterns and adaptive strategies between Gravettian and Early Epigravettian hunter-gatherers. Given the lack of any contextual evidence for change in climate, these differences are imputed to cultural factors and possibly linked to population replacement that may have taken place already at an early stage of the Epigravettian sequence. $^{47}$

Similarity in the distribution of artifact types between Italy and the Balkans, on the other hand, supports the possible expansion of techno-complexes from Central Europe via eastern/Slovenian routes and hint at long-distance mobility for Epigravettian hunter-gatherers. ${ }^{12}$ The same pattern, however, has been used to challenge this view in favor of a social network hypothesis. ${ }^{31}$ Similarity between Balkan and Italian contexts is documented from the Gravettian to the Mesolithic, and contacts involved raw lithic materials, marine molluscs, ornamental beads, clay figurines, decorative motives, and lithic technology. 5,30,32,48 At the same time, the reliability of some cultural markers (such as shouldered points) as proxies of human movement/interaction has been recently questioned. ${ }^{12}$

Uniparental genetic markers might be useful to disentangle the two proposed scenarios. The majority of samples attributed to the Villabruna Cluster (Figure 3) on a solid genetic and chronological basis share mtDNA and chrY belonging to a limited number of lineages. Reduced diversity within the uniparental Villabruna landscape is consistent either with a bottleneck interrupting the network or with a founder event in a broader scenario of population shift. ${ }^{10}$ This uniparental landscape, paired with evidence for seamless cultural exchange across the Adriatic ${ }^{12}$ and increased affinity with eastern genomic components, makes genetic replacement the most likely explanation for our results. The presence of Paglicci71 ( 18.5 ka ago) ${ }^{10}$ within the Villabruna maternal lineage advocates for a founder event in Southern Italy as early or even before $\sim 18.5 \mathrm{ka}$ ago, followed by a later expansion in Northern Italy at the beginning of deglaciation. In this light, Tagliente2 may be seen as an early settler of the Southern Alpine region, perhaps explaining the basal mtDNA lineage of this sample. The possibility of an earlier connection between Eastern and Western Europe through southern corridors, either in the form of an extended LGM network or as an early arrival of Villabruna-like individuals in Western Europe, is also supported by El Mirón, an lberian sample dated to $\sim 18.7$ ka ago ${ }^{9,12,27}$ presenting with an admixture of Magdalenian, Goyet-2-like ancestry and ancestry related to the Villabruna cluster. The most parsimonious interpretation of the emerging genetic scenario suggests that cumulative cultural change observed in Southern Europe from the 


\section{Current Biology Report}

end of LGM to the end of the Younger Dryas ( $11.7 \mathrm{ka}$ ago) was at least in part triggered by gene flow from southeastern refugia into Italy. This process, in its early stage and to the south of the Alps, was independent of the later Bølling-Allerød event and contributed to the gradual replacement of pre-LGM ancestry across the Italian peninsula ${ }^{49}$ and beyond. Further genetic evidence from Southern European contexts dated between $\sim 27$ and $19 \mathrm{ka}$ ago and analyses of cultural similarity between Italy and putative sources of population movement, however, will be needed in the future to test this hypothesis.

In conclusion, Tagliente2 provides evidence that the major migrations which strongly affected the genetic background of all Europeans $^{7-11}$ started considerably earlier in Southern Europe than previously reported and were already in place in this region during the cold phase following the LGM peak, possibly favored by stepwise reductions of glacier extent and forest expansion preceding the Bølling-Allerød rapid warming. At this stage, Southern Europe, the Balkans, and Eastern Europe/Western Asia were already connected into the same network of potential LGM refugia and exchanged both genes and cultural information, posing the basis for the observed population replacement. This finding also backdates previous conclusions concerning a plausible demic component to change over time in the coeval material culture of Southern Europe $\mathrm{e}^{7-11}$ and temporally locates this process at the transition between Early and Late Epigravettian or even possibly at the very beginning of the Epigravettian sequence.

\section{STAR $\star$ METHODS}

Detailed methods are provided in the online version of this paper and include the following:

- KEY RESOURCES TABLE

- RESOURCE AVAILABILITY

O Lead contact

O Materials availability

Data and code availability

- EXPERIMENTAL MODEL AND SUBJECT DETAILS

- METHOD DETAILS

O Palaeogeographic map of Europe at 17ka ago

- Radiocarbon dating

- DNA Extraction and Sequencing

o DNA extraction

O Library preparation

Sequencing filtering, mapping and variant calling analysis

O aDNA authentication

Calculating genetic sex estimation

Determining mtDNA and $Y$ chromosome haplogroups

- Anthropological and virtual analysis of Tagliente2

Histopathological examination

O Removal of Cementoma

- QUANTIFICATION AND STATISTICAL ANALYSIS

\section{SUPPLEMENTAL INFORMATION}

Supplemental information can be found online at https://doi.org/10.1016/j. cub.2021.03.078.

\section{ACKNOWLEDGMENTS}

This work is dedicated to the memory of the late Maurizio D'Esposito. The research was supported by the European Union through the European Research Council under the European Union's Horizon 2020 Research and Innovation Programme (grant agreement no. 724046 - SUCCESS awarded to S.B., http://www.erc-success.eu; grant agreement no. 803147 RESOLUTION awarded to S.T., https://site.unibo.it/resolution-erc/en) as well as through the European Regional Development Fund (project no. 2014-2020.4.01.16-0030 to C.L.S. and T.S.) and projects no. 20142020.4.01.16-0024 and MOBTT53 (L.P.), by the Estonian Research Council personal research grant (PRG243; C.L.S.), and by UniPd PRID 2019 (L.P.). We thank the Italian Ministry of Culture and Soprintendenza Archeologia Belle Arti e Paesaggio for the Provinces of Verona, Rovigo, and Vicenza for granting access to the human remains of Tagliente2. Research in the site of Riparo Tagliente was coordinated by the Museum of Natural History of Verona from 1964 to 1966 and resumed in 1967 under the direction of the University of Ferrara (Piero Leonardi, Alberto Broglio, Antonio Guerreschi), which still carries out investigation in the site (F.F.) under permission of the Italian Ministry of Culture. We are grateful to Dr. Francesca Rossi and Dr. Nicoletta Martinelli for giving access to human remains from Riparo Tagliente and for the support they provided during sampling. We also thank Dr. Elisabetta Cilli and Mr. Andrea De Giovanni for assistance with the preliminary documentation of the hemimandible Tagliente2.

\section{AUTHOR CONTRIBUTIONS}

Designed study, E.B., L.P., G.O., and S.B.; ran analyses, E.B., L.P., G.O., C.P., T.S., F.M., T.K., C.L.S., and S.T.; investigation, T.S. and C.L.S. (aDNA); wrote manuscript, E.B., L.P., G.O., F.F., F. Badino, M.R., F.L., M.P., and S.B.; provided samples, reagents, or sequences, F.F., R.A.C., C.L.S., S.T., M.D., and S.B.; contributed interpretation of results, C.P., F.F., F. Badino, D.M., M.R., F.L., A.P., M.B., N.P., A.O., S.A., C.F., G.M., S.S., F. Bernardini, J.C.M.S., L.F., J.M.C., C.T., T.K., F.G., M.P., S.T., and M.D.

\section{DECLARATION OF INTERESTS}

The authors declare no competing interests.

Received: September 8, 2020

Revised: January 7, 2021

Accepted: March 22, 2021

Published: April 21, 2021

\section{REFERENCES}

1. Lambeck, K., Rouby, H., Purcell, A., Sun, Y., and Sambridge, M. (2014). Sea level and global ice volumes from the Last Glacial Maximum to the Holocene. Proc. Natl. Acad. Sci. USA 111, 15296-15303.

2. Wren, C.D., and Burke, A. (2019). Habitat suitability and the genetic structure of human populations during the Last Glacial Maximum (LGM) in Western Europe. PLoS ONE 14, e0217996.

3. Vescovi, E., Ravazzi, C., Arpenti, E., Finsinger, W., Pini, R., Valsecchi, V., Wick, L., Ammann, B., and Tinner, W. (2007). Interactions between climate and vegetation during the Lateglacial period as recorded by lake and mire sediment archives in Northern Italy and Southern Switzerland. Quat. Sci. Rev. 26, 1650-1669.

4. Naudinot, N., Tomasso, A., Tozzi, C., and Peresani, M. (2014). Changes in mobility patterns as a factor of ${ }^{14} \mathrm{C}$ date density variation in the Late Epigravettian of Northern Italy and Southeastern France. J. Archaeol. Sci. 52, 578-590.

5. Fontana, F., Falceri, L., Gajardo, A., Bertola, S., Cremona, M.G., Cavulli, F., Guerreschi, A., and Visentin, D. (2018). Re-colonising the Southern Alpine fringe: diachronic data on the use of sheltered space in the late Epigravettian site of Riparo Tagliente. In Palaeolithic Italy. Advanced Studies on Early Human Adaptation in the Apennine Peninsula, V. Borgia, and E. Cristiani, eds. (Sidestone), pp. 287-310. 
6. Ravazzi, C., Pini, R., Badino, F., De Amicis, M., Londeix, L., and Reimer, P.J. (2014). The latest LGM culmination of the Garda Glacier (Italian Alps) and the onset of glacial termination. Age of glacial collapse and vegetation chronosequence. Quat. Sci. Rev. 105, 26-47.

7. Pala, M., Olivieri, A., Achilli, A., Accetturo, M., Metspalu, E., Reidla, M., Tamm, E., Karmin, M., Reisberg, T., Hooshiar Kashani, B., et al. (2012). Mitochondrial DNA signals of late glacial recolonization of Europe from near eastern refugia. Am. J. Hum. Genet. 90, 915-924.

8. Brewster, C., Meiklejohn, C., von Cramon-Taubadel, N., and Pinhasi, R. (2014). Craniometric analysis of European Upper Palaeolithic and Mesolithic samples supports discontinuity at the Last Glacial Maximum. Nat. Commun. 5, 4094.

9. Fu, Q., Posth, C., Hajdinjak, M., Petr, M., Mallick, S., Fernandes, D., Furtwängler, A., Haak, W., Meyer, M., Mittnik, A., et al. (2016). The genetic history of Ice Age Europe. Nature 534, 200-205.

10. Posth, C., Renaud, G., Mittnik, A., Drucker, D.G., Rougier, H., Cupillard, C., Valentin, F., Thevenet, C., Furtwängler, A., WiBing, C., et al. (2016). Pleistocene mitochondrial genomes suggest a single major dispersal of non-Africans and a Late Glacial population turnover in Europe. Curr. Biol. 26, 827-833.

11. Mathieson, I., Alpaslan-Roodenberg, S., Posth, C., Szécsényi-Nagy, A., Rohland, N., Mallick, S., Olalde, I., Broomandkhoshbacht, N., Candilio, F., Cheronet, O., et al. (2018). The genomic history of southeastern Europe. Nature 555, 197-203.

12. Peresani, M., Monegato, G., Ravazzi, C., Bertola, S., Margaritora, D., Breda, M., Fontana, A., Fontana, F., Janković, I., Karavanić, I., et al. (2020). Hunter-gatherers across the great Adriatic-Po region during the Last Glacial Maximum: environmental and cultural dynamics. Quat. Int. Published online October 15, 2020. https://doi.org/10.1016/j.quaint. 2020.10.007.

13. Monegato, G., Scardia, G., Hajdas, I., Rizzini, F., and Piccin, A. (2017). The Alpine LGM in the boreal ice-sheets game. Sci. Rep. 7, 2078.

14. Gazzoni, V., Goude, G., Herrscher, E., Guerreschi, A., Antonioli, F., and Fontana, F. (2013). Late Upper Palaeolithic human diet: first stable isotope evidence from Riparo Tagliente (Verona, Italy). Bull. Mem. Soc. Anthropol. Paris 25, 103-117.

15. Oxilia, G., Bortolini, E., Badino, F., Bernardini, F., Gazzoni, V., Lugli, F., et al. (2021). Exploring late Paleolithic and Mesolithic diet in the Eastern Alpine region of Italy through multiple proxies. Am. J. Phys. Anthropol. $174,232-253$.

16. Reimer, P.J., Austin, W.E.N., Bard, E., Bayliss, A., Blackwell, P.G., Ramsey, C.B., Butzin, M., Cheng, H., Edwards, R.L., Friedrich, M., et al. (2020). The IntCal20 northern hemisphere radiocarbon age calibration curve (0-55 cal kBP). Radiocarbon 62, 725-757.

17. Ramsey, C.B. (2017). Methods for summarizing radiocarbon datasets. Radiocarbon 59, 1809-1833.

18. Badino, F., Pini, R., Bertuletti, P., Ravazzi, C., Delmonte, B., Monegato, G., Reimer, P., Vallé, F., Arrighi, S., Bortolini, E., et al. (2020). The fastacting "pulse" of Heinrich Stadial 3 in a mid-latitude boreal ecosystem. Sci. Rep. 10, 18031.

19. Pini, R., Ravazzi, C., and Reimer, P.J. (2010). The vegetation and climate history of the last glacial cycle in a new pollen record from Lake Fimon (southern Alpine foreland, N-Italy). Quat. Sci. Rev. 29, 3115-3137.

20. Finsinger, W., Belis, C., Blockley, S.P.E., Eicher, U., Leuenberger, M., Lotter, A.F., and Ammann, B. (2008). Temporal patterns in lacustrine stable isotopes as evidence for climate change during the late glacial in the Southern European Alps. J. Paleolimnol. 40, 885-895.

21. Terlato, G., Bocherens, H., Romandini, M., Nannini, N., Hobson, K.A., and Peresani, M. (2019). Chronological and isotopic data support a revision for the timing of cave bear extinction in Mediterranean Europe. Hist. Biol. 31, 474-484.

22. Cooper, A., Turney, C., Hughen, K.A., Brook, B.W., McDonald, H.G., and Bradshaw, C.J. (2015). PALEOECOLOGY. Abrupt warming events drove Late Pleistocene Holarctic megafaunal turnover. Science 349, 602-606.
23. Rasmussen, S.O., Bigler, M., Blockley, S.P., Blunier, T., Buchardt, S.L., Clausen, H.B., Cvijanovic, I., Dahl-Jensen, D., Johnsen, S.J., Fischer, H., et al. (2014). A stratigraphic framework for abrupt climatic changes during the Last Glacial period based on three synchronized Greenland ice-core records: refining and extending the INTIMATE event stratigraphy. Quat. Sci. Rev. 106, 14-28.

24. Fu, Q., Mittnik, A., Johnson, P.L.F., Bos, K., Lari, M., Bollongino, R., Sun, C., Giemsch, L., Schmitz, R., Burger, J., et al. (2013). A revised timescale for human evolution based on ancient mitochondrial genomes. Curr. Biol. 23, 553-559.

25. Karmin, M., Saag, L., Vicente, M., Wilson Sayres, M.A., Järve, M., Talas, U.G., Rootsi, S., llumäe, A.M., Mägi, R., Mitt, M., et al. (2015). A recent bottleneck of $Y$ chromosome diversity coincides with a global change in culture. Genome Res. 25, 459-466.

26. Antonio, M.L., Gao, Z., Moots, H.M., Lucci, M., Candilio, F., Sawyer, S., Oberreiter, V., Calderon, D., Devitofranceschi, K., Aikens, R.C., et al. (2019). Ancient Rome: a genetic crossroads of Europe and the Mediterranean. Science 366, 708-714.

27. Villalba-Mouco, V., van de Loosdrecht, M.S., Posth, C., Mora, R., Martínez-Moreno, J., Rojo-Guerra, M., Salazar-García, D.C., RoyoGuillén, J.I., Kunst, M., Rougier, H., et al. (2019). Survival of Late Pleistocene Hunter-Gatherer Ancestry in the Iberian Peninsula. Curr. Biol. 29, 1169-1177.e7.

28. Montoya, C., and Peresani, M. (2005). Nouveaux éléments de diachronie dans l'Epigravettien récent des Préalpes de la Vénétie. In D'un Monde à L'autre : les Systèmes Lithiques Pendant le Tardiglaciaire Autour de la Méditerranée Nord-Occidentale: Actes de la Table-Ronde Internationale, Aix-en-Provence, 6-8 Juin 2001, J.-P. Bracco, and C. Montoya, eds. (Société Préhistorique Française), pp. 123-138.

29. Cancellieri, M. (2015). Over the Hills and Far Away. Last Glacial Maximum Lithic Technology around the Great Adriatic Plain (Archaeopress Publishing).

30. Boric, D., and Cristiani, E. (2016). Social networks and connectivity among the Palaeolithic and Mesolithic foragers of the Balkans and Italy. In Southeast Europe Before Neolithisation: Proceedings of the International Workshop within the Collaborative Research Centres SFB 1070 "RessourcenKulturen", Schloss Hohentübingen, 9th of May 2014, R. Krauss, and H. Floss, eds. (Universität Tübingen), pp. 73-112.

31. Tomasso, A. (2017). L'Épigravettien: variabilité diachronique et géographique. In Campo delle Piane: un Habitat de Plein air Épigravettien dans la Vallée du Gallero (Abruzzes, Italie Centrale), M. Olive, ed. (École Française de Rome), pp. 13-21.

32. Bertola, S., Fontana, F., and Visentin, D. (2018). Lithic raw material circulation and settlement dynamics in the Upper Palaeolithic of the Venetian Prealps (NE Italy). A key-role for palaeoclimatic and landscape changes across the LGM? In Palaeolithic Italy. Advanced Studies on Early Human Adaptations in the Apennine Peninsula, V. Borgia, and E. Cristiani, eds. (Sidestone), pp. 219-246.

33. Montoya, C., Duches, R., Fontana, F., Peresani, M., and Visentin, D. (2018). Peuplement tardiglaciaire et holocène ancien des Préalpes de la Vénétie (Italie Nord Orientale): éléments de confrontation. In L'Aquitaine à la Fin des Temps Glaciaires. Les Sociétés de la Transition du Paléolithique Final au Début du Mésolithique dans L'espace Nord Aquitain. Actes de la Table Ronde Organisée en Hommage à Guy Célérier, Les Eyzies-de-Tayac, 24-26 Juin 2015, PALEO, Numéro Spécial, A. Averbough, P. Jacquement-Bonnet, and J.-J. Cleyet-Merle, eds. (Musée National de Préhistoire), pp. 193-202.

34. Cristiani, E. (2018). Epigravettian osseous technology from the eastern Alpine region of Italy: the case of Riparo Dalmeri (Trentino). In Palaeolithic Italy. Advanced Studies on Early Human Adaptation in the Apennine Peninsula, V. Borgia, and E. Cristiani, eds. (Sidestone), pp. 311-334.

35. Wirsig, C., Zasadni, J., Ivy-Ochs, S., Christl, M., Kober, F., and Schlüchter, C. (2016). A deglaciation model of the Oberhasli, Switzerland. J. Quat. Sci. 31, 46-59. 


\section{Current Biology}

\section{Report}

36. Monegato, G., and Ravazzi, C. (2018). The Late Pleistocene multifold glaciation in the Alps: updates and open questions. Al. Med. Quat. 31, 225-229.

37. Bolland, A., Rey, F., Gobet, E., Tinner, W., and Heiri, O. (2020). Summer temperature development 18,000-14,000 cal. BP recorded by a new chironomid record from Burgäschisee, Swiss Plateau. Quat. Sci. Rev. 243, 106484

38. Fontana, A., Mozzi, P., and Marchetti, M. (2014). Alluvial fans and megafans along the southern side of the Alps. Sediment. Geol. 301, 150-171.

39. Romandini, M., and Nannini, N. (2012). Chasseurs épigravettiens dans le territoire de l'ours des cavernes: le cas du Covolo Fortificato di Trene (Vicenza, Italie). L'Anthropologie 116, 39-56.

40. Romandini, M., Bertola, S., and Nannini, N. (2015). Nuovi dati sul Paleolitico dei Colli Berici: risultati preliminari dello studio archeozoologico e delle materie prime litiche della Grotta del Buso Doppio del Broion (Lumignano, Longare, Vicenza). Studi di Preistoria e Protostoria 2, 53-59.

41. Carrera, L., Pavia, M., Romandini, M., and Peresani, M. (2018). Avian fossil assemblages at the onset of the LGM in the eastern Alps: a palaecological contribution from the Rio Secco Cave (Italy). Comptes Rendus Palevol 17, 166-177.

42. Peresani, M. (2006). Cultures et traditions du Paléolithique supérieur dans les régions nord-méditerranéennes. In La Cuenca Mediterránea durante el Paleolítico Superior (38.000-10.000 años), J.L. Sanchidrián, A.M. Márquez Alcántara, and J.M. Fullola i Pericot, eds. (Fundación Cueva de Nerja), pp. 408-429.

43. Straus, L.G. (2013). After the deep freeze: confronting "Magdalenian" realities in Cantabrian Spain and beyond. J. Archaeol. Method Theory 20, 236-255.

44. Tallavaara, M., Luoto, M., Korhonen, N., Järvinen, H., and Seppä, H. (2015). Human population dynamics in Europe over the Last Glacial Maximum. Proc. Natl. Acad. Sci. USA 112, 8232-8237.

45. Timmermann, A., and Friedrich, T. (2016). Late Pleistocene climate drivers of early human migration. Nature 538, 92-95.

46. Berto, C., Luzi, E., Canini, G.M., Guerreschi, A., and Fontana, F. (2018). Climate and landscape in Italy during Late Epigravettian. The Late Glacial small mammal sequence of Riparo Tagliente (Stallavena di Grezzana, Verona, Italy). Quat. Sci. Rev. 184, 132-142.

47. Lugli, F., Cipriani, A., Capecchi, G., Ricci, S., Boschin, F., Boscato, P., lacumin, P., Badino, F., Mannino, M.A., Talamo, S., et al. (2019). Strontium and stable isotope evidence of human mobility strategies across the Last Glacial Maximum in southern Italy. Nat. Ecol. Evol. 3, 905-911.

48. Cristiani, E., Farbstein, R., and Miracle, P. (2014). Ornamental traditions in the Eastern Adriatic: The Upper Palaeolithic and Mesolithic personal adornments from Vela Spila (Croatia). J. Anthropol. Archaeol. 36, 21-31.

49. Catalano, G., Lo Vetro, D., Fabbri, P.F., Mallick, S., Reich, D., Rohland, N., Sineo, L., Mathieson, I., and Martini, F. (2020). Late Upper Palaeolithic hunter-gatherers in the Central Mediterranean: New archaeological and genetic data from the Late Epigravettian burial Oriente C (Favignana, Sicily). Quat. Int. 537, 24-32.

50. Fortes, G.G., Grandal-d'Anglade, A., Kolbe, B., Fernandes, D., Meleg, I.N., García-Vázquez, A., Pinto-Llona, A.C., Constantin, S., de Torres, T.J., Ortiz, J.E., et al. (2016). Ancient DNA reveals differences in behaviour and sociality between brown bears and extinct cave bears. Mol. Ecol. 25, 4907-4918.

51. Stuart, A.J., and Lister, A.M. (2007). Patterns of Late Quaternary megafaunal extinctions in Europe and northern Asia. Cour. Forsch.-Inst. Senckenberg 259, 287-297.

52. Barnosky, A.D., Koch, P.L., Feranec, R.S., Wing, S.L., and Shabel, A.B. (2004). Assessing the causes of late Pleistocene extinctions on the continents. Science 306, 70-75.

53. Lorenzen, E.D., Nogués-Bravo, D., Orlando, L., Weinstock, J., Binladen, J., Marske, K.A., Ugan, A., Borregaard, M.K., Gilbert, M.T., Nielsen, R., et al. (2011). Species-specific responses of Late Quaternary megafauna to climate and humans. Nature $479,359-364$.

54. Pacher, M., and Stuart, A.J. (2009). Extinction chronology and palaeobiology of the cave bear (Ursus spelaeus). Boreas 38, 189-206.

55. Stuart, A.J. (2015). Late Quaternary megafaunal extinctions on the continents: a short review. Geol. J. 50, 338-363.

56. Lowe, J.J., Rasmussen, S.O., Björck, S., Hoek, W.Z., Steffensen, J.P., Walker, M.J.C., and Yu, Z.C.; the INTIMATE group (2008). Synchronisation of palaeoenvironmental events in the North Atlantic region during the Last Termination: a revised protocol recommended by the INTIMATE group. Quat. Sci. Rev. 27, 6-17.

57. Oeggl, K., and Wahlmüller, N. (1994). Vegetation and Climate History of a High Alpine Mesolithic Camp Site in the Eastern Alps (Museo Tridentino di Scienze Naturali).

58. Fontana, F., and Visentin, D. (2016). Between the Venetian Alps and the Emilian Apennines (Northern Italy): Highland vs. lowland occupation in the early Mesolithic. Quat. Int. 423, 266-278.

59. Stiner, M.C., Kuhn, S.L., Weiner, S., and Bar-Yosef, O. (1995). Differential burning, recrystallization, and fragmentation of archaeological bone. J. Archaeol. Sci. 22, 223-237.

60. Longin, R. (1971). New method of collagen extraction for radiocarbon dating. Nature 230, 241-242.

61. Brown, T.A., Nelson, D.E., Vogel, J.S., and Southon, J.R. (1988). Improved collagen extraction by modified Longin method. Radiocarbon 30, 171-177.

62. Brock, F., Ramsey, C., and Higham, T. (2007). Quality assurance of ultrafiltered bone dating. Radiocarbon 49, 187-192.

63. Korlević, P., Talamo, S., and Meyer, M. (2018). A combined method for DNA analysis and radiocarbon dating from a single sample. Sci. Rep. $8,4127$.

64. Bartolomei, G., Broglio, A., Guerreschi, A., Leonardi, P., Peretto, C., and Sala, B. (1974). Una sepoltura epigravettiana nel deposito pleistocenico del Riparo Tagliente in Valpantena (Verona). Riv. Sci. Preistoriche 29, 101-152.

65. Fontana, F., Cilli, C., Cremona, M.G., Giacobini, G., Gurioli, F., Liagre, J., Malerba, G., Rocci Ris, A., Veronese, C., and Guerreschi, A. (2009). Recent data on the Late Epigravettian occupation at Riparo Tagliente, Monti Lessini (Grezzana, Verona): a multidisciplinary perspective. Preistoria Alp. 44, 51-59.

66. Corrain, C. (1966). Un frammento di mandibola umana, rinvenuto a "Riparo Tagliente" in Valpantena (Verona). Atti Dell'Istituto Veneto Sci. Lett. Ed. Arti. 124, 23-26.

67. Corrain, C. (1978). I resti scheletrici umani della sepoltura epigravettiana del Riparo Tagliente in Valpantena (Verona). Boll. Mus. Civ. Storia Nat. Verona 4, 35-79.

68. Hughes, A.L.C., Gyllencreutz, R., Lohne, Ø.S., Mangerud, J., and Svendsen, J.I. (2016). The last Eurasian ice sheets - a chronological database and time-slice reconstruction, DATED-1. Boreas 45, 1-45.

69. Seguinot, J., Ivy-Ochs, S., Jouvet, G., Huss, M., Funk, M., and Preusser F. (2018). Modelling last glacial cycle ice dynamics in the Alps. Cryosphere 12, 3265-3285.

70. Luetscher, M., Boch, R., Sodemann, H., Spötl, C., Cheng, H., Edwards, R.L., Frisia, S., Hof, F., and Müller, W. (2015). North Atlantic storm track changes during the Last Glacial Maximum recorded by Alpine speleothems. Nat. Commun. 6, 6344.

71. Lofverstrom, M. (2020). A dynamic link between high-intensity precipitation events in southwestern North America and Europe at the Last Glacial Maximum. Earth Planet. Sci. Lett. 534, 116081.

72. Ivy-Ochs, S., Kerschner, H., Reuther, A., Preusser, F., Heine, K., Maisch, M., Kubik, P.W., and Schlüchter, C. (2008). Chronology of the last glacial cycle in the European Alps. J. Quat. Sci. 23, 559-573.

73. Pellegrini, C., Maselli, V., Cattaneo, A., Piva, A., Ceregato, A., and Trincardi, F. (2015). Anatomy of a compound delta from the post-glacial transgressive record in the Adriatic Sea. Mar. Geol. 362, 43-59. 
74. Maselli, V., Trincardi, F., Asioli, A., Ceregato, A., Rizzetto, F., and Taviani, M. (2014). Delta growth and river valleys: the influence of climate and sea level changes on the South Adriatic shelf (Mediterranean Sea). Quat. Sci. Rev. 99, 146-163.

75. Münzel, S.C., Stiller, M., Hofreiter, M., Mittnik, A., Conard, N.J., and Bocherens, H. (2011). Pleistocene bears in the Swabian Jura (Germany): genetic replacement, ecological displacement, extinctions and survival. Quat. Int. 245, 225-237.

76. Gretzinger, J., Molak, M., Reiter, E., Pfrengle, S., Urban, C., Neukamm, J., Blant, M., Conard, N.J., Cupillard, C., Dimitrijević, V., et al. (2019). Large-scale mitogenomic analysis of the phylogeography of the Late Pleistocene cave bear. Sci. Rep. 9, 10700.

77. Moran, A.P., Ivy-Ochs, S., Schuh, M., Christl, M., and Kerschner, H. (2016). Evidence of central Alpine glacier advances during the Younger Dryas-early Holocene transition period. Boreas 45, 398-410.

78. Fontana, F., Guerreschi, A., and Peresani, M. (2011). The visible landscape: Inferring Mesolithic settlement dynamics from multifaceted evidence in the south-eastern Alps. In Hidden Landscapes of Mediterranean Europe: Cultural and Methodological Biases in Pre-and Protohistoric Landscape Studies. Proceedings of the International Meeting (Siena 2007), M. van Leusen, G. Pizziolo, and L. Sarti, eds. (BAR Publishing), pp. 71-81.

79. Higham, T.F.G., Jacobi, R.M., and Ramsey, C.B. (2006). AMS radiocarbon dating of ancient bone using ultrafiltration. Radiocarbon 48, 179-195.

80. van Klinken, G.J. (1999). Bone collagen quality indicators for palaeodietary and radiocarbon measurements. J. Archaeol. Sci. 26, 687-695.

81. Kromer, B., Lindauer, S., Synal, H.-A., and Wacker, L. (2013). MAMS - A new AMS facility at the Curt-Engelhorn-Centre for Achaeometry, Mannheim, Germany. Nucl. Instrum. Methods Phys. Res. B 294, 11-13.

82. Meyer, M., and Kircher, M. (2010). Illumina sequencing library preparation for highly multiplexed target capture and sequencing. Cold Spring Harb. Protoc. 2010, pdb.prot5448.

83. Orlando, L., Ginolhac, A., Zhang, G., Froese, D., Albrechtsen, A., Stiller, M., Schubert, M., Cappellini, E., Petersen, B., Moltke, I., et al. (2013). Recalibrating Equus evolution using the genome sequence of an early Middle Pleistocene horse. Nature 499, 74-78.

84. Malaspinas, A.-S., Lao, O., Schroeder, H., Rasmussen, M., Raghavan, M., Moltke, I., Campos, P.F., Sagredo, F.S., Rasmussen, S., Gonçalves, V.F., et al. (2014). Two ancient human genomes reveal Polynesian ancestry among the indigenous Botocudos of Brazil. Curr. Biol. 24, R1035-R1037.

85. Magoč, T., and Salzberg, S.L. (2011). FLASH: fast length adjustment of short reads to improve genome assemblies. Bioinformatics 27, 29572963.

86. Martin, M. (2011). Cutadapt removes adapter sequences from highthroughput sequencing reads. EMBnet.J. 17, 10-12.

87. Li, H., and Durbin, R. (2009). Fast and accurate short read alignment with Burrows-Wheeler transform. Bioinformatics 25, 1754-1760.

88. Li, H., Handsaker, B., Wysoker, A., Fennell, T., Ruan, J., Homer, N., Marth, G., Abecasis, G., and Durbin, R.; 1000 Genome Project Data Processing Subgroup (2009). The Sequence Alignment/Map format and SAMtools. Bioinformatics 25, 2078-2079.

89. McKenna, A., Hanna, M., Banks, E., Sivachenko, A., Cibulskis, K., Kernytsky, A., Garimella, K., Altshuler, D., Gabriel, S., Daly, M., and DePristo, M.A. (2010). The Genome Analysis Toolkit: a MapReduce framework for analyzing next-generation DNA sequencing data. Genome Res. 20, 1297-1303.

90. Jónsson, H., Ginolhac, A., Schubert, M., Johnson, P.L.F., and Orlando, L. (2013). mapDamage2.0: fast approximate Bayesian estimates of ancient DNA damage parameters. Bioinformatics 29, 1682-1684.

91. Jones, E.R., Zarina, G., Moiseyev, V., Lightfoot, E., Nigst, P.R., Manica, A., Pinhasi, R., and Bradley, D.G. (2017). The Neolithic transition in the
Baltic was not driven by admixture with early European farmers. Curr. Biol. 27, 576-582

92. Skoglund, P., Storå, J., Götherström, A., and Jakobsson, M. (2013). Accurate sex identification of ancient human remains using DNA shotgun sequencing. J. Archaeol. Sci. 40, 4477-4482.

93. Fu, Q., Li, H., Moorjani, P., Jay, F., Slepchenko, S.M., Bondarev, A.A., Johnson, P.L., Aximu-Petri, A., Prüfer, K., de Filippo, C., et al. (2014). Genome sequence of a 45,000-year-old modern human from western Siberia. Nature 514, 445-449.

94. Weissensteiner, H., Pacher, D., Kloss-Brandstätter, A., Forer, L., Specht, G., Bandelt, H.-J., Kronenberg, F., Salas, A., and Schönherr, S. (2016). HaploGrep 2: mitochondrial haplogroup classification in the era of high-throughput sequencing. Nucleic Acids Res. 44, W58-W63.

95. Poznik, G.D., Xue, Y., Mendez, F.L., Willems, T.F., Massaia, A., Wilson Sayres, M.A., Ayub, Q., McCarthy, S.A., Narechania, A., and Kashin, S.; The 1000 Genomes Project Consortium (2016). Punctuated bursts in human male demography inferred from 1,244 worldwide Y-chromosome sequences. Nat. Genet. 48, 593-599.

96. Korneliussen, T.S., Albrechtsen, A., and Nielsen, R. (2014). ANGSD: Analysis of Next Generation Sequencing Data. BMC Bioinformatics 15, 356 .

97. Quinlan, A.R. (2014). BEDTools: the Swiss-Army tool for genome feature analysis. Curr. Protoc. Bioinformatics 47, 11.12.1-11.12.34.

98. Smith, B.H. (1984). Patterns of molar wear in hunger-gatherers and agriculturalists. Am. J. Phys. Anthropol. 63, 39-56.

99. Young, S.K., Markowitz, N.R., Sullivan, S., Seale, T.W., and Hirschi, R. (1989). Familial gigantiform cementoma: classification and presentation of a large pedigree. Oral Surg. Oral Med. Oral Pathol. 68, 740-747.

100. Henthorn, P.S., Raducha, M., Fedde, K.N., Lafferty, M.A., and Whyte, M.P. (1992). Different missense mutations at the tissue-nonspecific alkaline phosphatase gene locus in autosomal recessively inherited forms of mild and severe hypophosphatasia. Proc. Natl. Acad. Sci. USA 89, 99249928.

101. Divisato, G., Formicola, D., Esposito, T., Merlotti, D., Pazzaglia, L., Del Fattore, A., Siris, E., Orcel, P., Brown, J.P., Nuti, R., et al. (2016). ZNF687 mutations in severe Paget disease of bone associated with giant cell tumor. Am. J. Hum. Genet. 98, 275-286.

102. Carpten, J.D., Robbins, C.M., Villablanca, A., Forsberg, L., Presciuttini, S., Bailey-Wilson, J., Simonds, W.F., Gillanders, E.M., Kennedy, A.M., Chen, J.D., et al. (2002). HRPT2, encoding parafibromin, is mutated in hyperparathyroidism-jaw tumor syndrome. Nat. Genet. 32, 676-680.

103. Behjati, S., Tarpey, P.S., Presneau, N., Scheipl, S., Pillay, N., Van Loo, P., Wedge, D.C., Cooke, S.L., Gundem, G., Davies, H., et al. (2013). Distinct H3F3A and H3F3B driver mutations define chondroblastoma and giant cell tumor of bone. Nat. Genet. 45, 1479-1482.

104. Fittall, M.W., Mifsud, W., Pillay, N., Ye, H., Strobl, A.C., Verfaillie, A., Demeulemeester, J., Zhang, L., Berisha, F., Tarabichi, M., et al. (2018). Recurrent rearrangements of FOS and FOSB define osteoblastoma. Nat. Commun. 9, 2150.

105. Patterson, N., Moorjani, P., Luo, Y., Mallick, S., Rohland, N., Zhan, Y., Genschoreck, T., Webster, T., and Reich, D. (2012). Ancient admixture in human history. Genetics 192, 1065-1093.

106. Skoglund, P., Mallick, S., Bortolini, M.C., Chennagiri, N., Hünemeier, T., Petzl-Erler, M.L., Salzano, F.M., Patterson, N., and Reich, D. (2015) Genetic evidence for two founding populations of the Americas. Nature 525, 104-108.

107. Nei, M., and Kumar, S. (2000). Molecular Evolution and Phylogenetics (Oxford University).

108. Kumar, S., Stecher, G., Li, M., Knyaz, C., and Tamura, K. (2018). MEGA X: Molecular Evolutionary Genetics Analysis across computing platforms. Mol. Biol. Evol. 35, 1547-1549.

109. Stecher, G., Tamura, K., and Kumar, S. (2020). Molecular Evolutionary Genetics Analysis (MEGA) for macOS. Mol. Biol. Evol. 37, 1237-1239. 


\section{Current Biology}

Report

\section{STAR $\star M E T H O D S$}

\section{KEY RESOURCES TABLE}

\begin{tabular}{|c|c|c|}
\hline REAGENT or RESOURCE & SOURCE & IDENTIFIER \\
\hline \multicolumn{3}{|l|}{ Biological samples } \\
\hline $\begin{array}{l}\text { Human archaeological remains - left } \\
\text { hemimandible from Riparo Tagliente }\end{array}$ & This paper & Tagliente2 \\
\hline \multicolumn{3}{|l|}{ Critical commercial assays } \\
\hline High Pure Viral Nucleic Acid Large Volume Kit & Roche & 05114403001 \\
\hline NEBNext DNA Library Prep & New England & E6070 \\
\hline Master Mix Set for 454 & Biolabs & N/A \\
\hline \multicolumn{3}{|l|}{ Deposited data } \\
\hline Tagliente2 genome & This study & http://www.ebc.ee/free_data/Bortolini_2020/ \\
\hline Ancient DNA comparison dataset & David Reich's lab, Harvard & https://reich.hms.harvard.edu/datasets \\
\hline Human reference genome NCBI build 37, GRCh37 & Genome Reference Consortium & $\begin{array}{l}\text { https://www.ncbi.nlm.nih.gov/projects/genome/ } \\
\text { assembly/grc/human/ }\end{array}$ \\
\hline \multicolumn{3}{|l|}{ Software and algorithms } \\
\hline FLASH & Fortes et al. ${ }^{50}$ & https://doi.org/10.1093/bioinformatics/btr507 \\
\hline cutadapt-1.11 & Stuart and Lister ${ }^{51}$ & https://doi.org/10.14806/ej.17.1.200 \\
\hline Burrows-Wheeler Aligner (BWA) & Barnosky et al. ${ }^{52}$ & http://bio-bwa.sourceforge.net/ \\
\hline Samtools & Lorenzen et al. ${ }^{53}$ & http://samtools.sourceforge.net/ \\
\hline Picard 2.12 & Broad Institute 2019 & http://broadinstitute.github.io/picard/index.html \\
\hline GATK & Pacher and Stuart ${ }^{54}$ & https://gatk.broadinstitute.org \\
\hline mapDamage2.0 & Stuart $^{55}$ & https://ginolhac.github.io/mapDamage/ \\
\hline sex identification algorithm & Lowe et al. ${ }^{56}$ & $\begin{array}{l}\text { https://www.sciencedirect.com/science/article/ } \\
\text { pii/S0305440313002495 }\end{array}$ \\
\hline \multirow[t]{2}{*}{ HaploGrep2 } & Oeggl and Wahlmüller ${ }^{57}$ & https://doi.org/10.1093/nar/gkw233 \\
\hline & & https://github.com/seppinho/haplogrep-cmd \\
\hline ANGSD & Fontana and Visentin ${ }^{58}$ & http://www.popgen.dk/angsd/index.php/ANGSD \\
\hline BEDTools 2.19 & Stiner et al. ${ }^{59}$ & https://bedtools.readthedocs.io/en/latest/ \\
\hline f3, f4, qpGraph, ADMIXTOOLS & Longin 60 & https://github.com/DReichLab/AdmixTools \\
\hline popstats & Brown et al. ${ }^{61}$ & $\begin{array}{l}\text { https://github.com/pontussk/popstats/blob/ } \\
\text { master/README.md }\end{array}$ \\
\hline \multirow[t]{2}{*}{ MEGA $X$} & Brock et al. ${ }^{62}$ and Korlević et al. ${ }^{63}$ & $\begin{array}{l}\text { https://academic.oup.com/mbe/article/37/ } \\
\text { 4/1237/5697095 }\end{array}$ \\
\hline & & https://www.megasoftware.net/ \\
\hline Geomagic Design X (Figure 1B) & 3D System & $\begin{array}{l}\text { https://www.3dsystems.com/software/geomagic- } \\
\text { design-x }\end{array}$ \\
\hline NIS D 3.0 & Nikon & $\begin{array}{l}\text { https://www.nikon.com/products/microscope- } \\
\text { solutions/support/download/software/imgsfw/ } \\
\text { nis-d_v5020364.htm }\end{array}$ \\
\hline \multicolumn{3}{|l|}{ Other } \\
\hline $\begin{array}{l}\text { Data for palaeogeographic map (Figure } 1 \mathrm{~A} \text { ): } \\
\text { DEM (base topography) }\end{array}$ & $\begin{array}{l}\text { Copernicus Land Monitoring } \\
\text { Service } 2019 \text { (CLMS) }\end{array}$ & https://land.copernicus.eu/pan european \\
\hline $\begin{array}{l}\text { Data for palaeogeographic map (Figure } 1 \mathrm{~A} \text { ): } \\
\text { Bathymetric data (base topography) }\end{array}$ & $\begin{array}{l}\text { General Bathymetric Chart of } \\
\text { the Oceans (GEBCO } 2019 \text { grid) }\end{array}$ & $\begin{array}{l}\text { https://doi.org/10.5285/836f016a-33be-6ddc- } \\
\text { e053-6c86abc0788e }\end{array}$ \\
\hline $\begin{array}{l}\text { Data for palaeogeographic map (Figure } 1 \mathrm{~A} \text { ): } \\
\text { Sea level drop at }-110 \mathrm{~m}\end{array}$ & 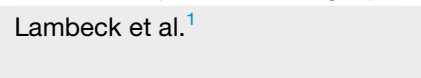 & https://doi.org/10.1073/pnas.1411762111 \\
\hline
\end{tabular}




\section{Current Biology Report}

\begin{tabular}{|c|c|c|}
\hline \\
\hline REAGENT or RESOURCE & \multicolumn{2}{|c|}{$\begin{array}{l}\text { Continued } \\
\text { REAGENT or RESOURCE }\end{array}$} \\
\hline \multicolumn{2}{|c|}{$\begin{array}{l}\text { Data for palaeogeographic map (Figure 1A): } \quad \text { Badino et al. }^{18} \\
\text { mountain glaciers at LGM and freshwater } \\
\text { systems }\end{array}$} & https://dx.doi.org/10.1016/j.quaint.2019.09.024 \\
\hline $\begin{array}{l}\text { Data for palaeogeographic map (Figure } 1 \mathrm{~A}) \text { : } \\
\text { Scandinavian and British Islands ice sheets } \\
\text { at } 17 \mathrm{ka} \text { ago }\end{array}$ & Karmin et al. ${ }^{25}$ & https://doi.org/10.1111/bor.12142 \\
\hline $\begin{array}{l}\text { Data for palaeogeographic map (Figure } 1 \mathrm{~A}) \text { : } \\
\text { Alpine Glaciers extent at } 17 \mathrm{ka} \text { ago }\end{array}$ & Bartolomei et al. ${ }^{64}$ & https://doi.org/10.5446/35164 \\
\hline
\end{tabular}

\section{RESOURCE AVAILABILITY}

\section{Lead contact}

Further information and requests for resources and reagents should be directed to and will be fulfilled by the Lead Contact, Eugenio Bortolini (eugenio.bortolini2@unibo.it)

\section{Materials availability}

X-ray microCT scans and the digital model obtained after segmentation of the mandibular section interested by cementoma are currently stored at the Virtual Antropology section of Bones Lab, University of Bologna, and can be accessed upon request (Gregorio Oxilia).

Data and code availability

Whole genome sequences generated for this study are freely available for download at http://www.ebc.ee/free_data/Bortolini_2020/.

\section{EXPERIMENTAL MODEL AND SUBJECT DETAILS}

A new genomic sequence and direct dating were obtained for the hemimandible Tagliente2, uncovered at Riparo Tagliente (Stallavena di Grezzana, Verona, Italy). The anthropological materials found at Ripato Tagliente are currently stored at the Natural History Museum of Verona. Permission to access the hemimandible was granted by the SABAP of Verona, Rovigo and Vicenza (Veneto Archaeological Superintendency, Ministry of Cultural Heritage and Activities of Italy) which is legally responsible for the conservation and scientific study of the skeletal remains found at the site. The shelter is located on the left slope of Valpantena, one of the main valley bottoms of the pre-Alpine massif of Monti Lessini. The site lies under a rock-shelter and was discovered in 1958 by Mr. Francesco Tagliente. It opens at the base of Monte Tregnago under a bank of oolitic limestones at an altitude of $250 \mathrm{~m}$ a.s.I. Archaeological investigations were carried out by the Museo Civico di Storia Naturale of Verona from 1962 to 1964 and resumed by the University of Ferrara since 1967. The site preserves a stratigraphic series which reaches a thickness of over $4.50 \mathrm{~m}$ in the outer area of the rock-shelter. Such sequence is formed by two main deposits separated by river erosion: the lower deposit contains evidence of Mousterian and Aurignacian occupations and the upper one is characterized by rich record related to several intense Late Epigravettian settlement occurrences. ${ }^{64}$ According to radiocarbon dates which range from 17,219-16,687 cal BP (layer 13 alpha) to 14,572-13,430 cal BP 14535-13472 (levels 10-8), the Epigravettian series is one of the most complete in northern Italy spanning from the first part of the Lateglacial to the the Bølling-Allerød interstadial. ${ }^{5,65}$

The hemimandible Tagliente2 was found in 1963 during the first excavation campaigns in the site within disturbed sediments located immediately outside the shelter. ${ }^{66}$ According to excavators such sediments could come from the inner area of the shelter and have been removed during historical excavations in the uppermost deposits which had led to destruction of part of the prehistoric stratigraphic sequence and dumping of sediments outside the shelter entrance. An in situ burial was found ten years later (1973) at the southern edge of the sheltered area. ${ }^{64}$ The burial had been partially destroyed by the same historical excavations. Nonetheless the lowermost part of the skeleton - from the pelvis to the feet - was well preserved in the grave while only a few ribs and vertebrae, the distal fragments of the radius and ulna and some phalanxes were collected on the trampling floor of the artificial chamber created by historical excavations. The skeleton was contained in a $60 \mathrm{~cm}$ deep and $60 \mathrm{~cm}$ wide pit with a concave section. It had been laid in a supine position with outstretched arms. The original composition of the grave goods assemblage is unknown due to the incompleteness of the burial but a limestone pebble covered with traces of ochre was found between the feet and a fragment of bovid horn near the right femur. The intentional deposition of a pierced Cyclope collected near the left knee is uncertain. The legs were covered with some limestones blocks of different dimensions. A large stone located on the femurs was characterized by engravings of a lion and the horn of an auroch. ${ }^{64}$ The skeleton belonged to a young adult male aged $20-29$ years and about $163 \mathrm{~cm}$ tall. ${ }^{67}$ Carbon and nitrogen stable isotope analysis performed on the bone collagen from the partial skeleton (from a rib) and 11 faunal remains from layers consistent with the burial deposition, suggests that the human individual had a terrestrial diet integrated by consumption of aquatic resources. ${ }^{14}$ Radiocarbon dating of the hemimandible, of the partial burial and the stratigraphic position of the burial pit, which 


\section{Current Biology Report}

intersects the Mousterian deposits, shows consistency with the first phase of Late Epigravettian occupation in the site. At Riparo Tagliente, layers referred to this period are better known in the northern sector where they have been extensively explored in the area protected by the rock-shelter over a surface of around 20 s.q.m.

\section{METHOD DETAILS}

Palaeogeographic map of Europe at $17 \mathrm{ka}$ ago

Coordinate system ETRS89 / UTM zone 32N (EPSG 25832); Digital Elevation Model (base topography - Copernicus Land Monitoring Service 2019 (CLMS, https://land.copernicus.eu/pan european), and General Bathymetric Chart of the Oceans (GEBCO 2019 grid, https://doi.org/10.5285/836f016a-33be-6ddc-e053-6c86abc0788e). Sea level drop at - $110 \mathrm{~m} .{ }^{1}$ Scandinavian and British Islands ice sheets, mountain glaciers Last Glacial Maximum (LGM) extent (striped areas) and freshwater systems modified after Badino et al. ${ }^{18}$ Scandinavian and British Islands ice sheets (pale blue) at $17 \mathrm{ka}$ after Hughes et al. ${ }^{68}$ Alpine glaciers extent (dashed outline) modeled at 17 ka from Seguinot et al. ${ }^{69}$ (https://doi.org/10.5446/35164). Modeled extension is generally underestimated in the northwestern Alps and overestimated in the eastern and south-western Alps. ${ }^{69}$

The period ranging between the Last Glacial Maximum (LGM) and the onset of the Holocene (ca. 30-11 ka cal BP) experienced large-scale climate changes that produced distinctive local and regional ecological and bio-cultural responses (Figure 1). This time interval is characterized by large migratory events of modern human populations linked to dramatic changes in demography, human behavior, and the appearance of various material culture complexes ${ }^{10}$ (Figure 1). Glaciated Alps represented an effective physiographic barrier for meridional moist advection ${ }^{70,71}$ supporting tree growth and boreal forests in the southern alpine foreland.

A phase of major forest contraction occurred between ca. 26 to $21 \mathrm{ka}$ cal BP during the GS-3 stadial (Figure 1C). At this time, European mountain glaciers expanded ${ }^{13,68}$ and large piedmont glaciers advanced onto the Alpine foreland around $25 \mathrm{ky}$ ago (e.g., Monegato et al. ${ }^{13}$ and Ivy-Ochs et al. ${ }^{72}$ ). A continental shelf emerged as consequence of extreme sea level fall (i.e., $\sim 120$ $\mathrm{m}^{73,74}$ ) connecting the Balkans to the Western Mediterranean regions with a major role in driving large-scale migratory fluxes of Gravettian-Postgravettian hunter-gatherers. During the LGM culmination there is at present no direct evidence of megafaunal extinction events (Figure 1C). The extinction of Cave bears, ${ }^{21}$ is one of the most relevant issues of the Late Quaternary ${ }^{22}$ whose main causes are human hunting and interference ${ }^{50,75}$ and climate change. ${ }^{51-55,76}$ On the other hand, major megafaunal (mainly steppe taxa) extinction events rather appear to be associated with warming events toward the end of the Pleistocene ( 14 to $11 \mathrm{ka}$; Figure 1C). During the interval ranging between ca. 19-11.7 ka years cal BP, the Epigravettian colonization of the Alps, Apennines, and the Dinarids started. After ca. $18 \mathrm{ka}$, the deglaciation was characterized by dynamic glacial fluctuations ${ }^{69}$ (Figure $1 \mathrm{~A}$ ) through the two combined processes of down melting (in altitudes) and ice-retreat controlled by slope-damming processes along the valley floors. Pine-birch groves and open larch stands established in the South-Alpine foreland, while open woodland of spruce, pine and larch with a juniper understorey colonized ice-free areas in the eastern Pre-Alps. ${ }^{3,6}$ During this period the first human occurrence at the foot of the Pre-Alps is documented at Riparo Tagliente. ${ }^{65}$

This phase was followed by an abrupt shift to warmer conditions at ca. $14.7 \mathrm{ka}$ cal BP (onset of Bølling-Allerød interstadial period, Gl-1e in the Greenland ice record) (Figure 1C), which promoted the displacement of alpine habitats to higher altitudes and an increase in woodland density with dominance of pine, larch, spruce and birch. ${ }^{3}$ The second part of this Interstadial was marked by the expansion of mixed oak forests in the Po plain and submountain belt. Such favorable climatic conditions promoted the increase in the number of Epigravettian sites and also a gradual colonization of high altitudes (i.e., above $1000 \mathrm{~m}$ a.s.l.). Renewed cold conditions occurred at the beginning of the Younger Dryas (YD, also regarded as event GS 1 in Greenland ice cores; ca. 12.9 -11.7 ka cal BP; e.g., Lowe et al. ${ }^{56}$; Figure 1C). It certainly had strong effects on stands of thermophilous trees formerly expanded in the forelands of the Southern Alps. During the second half of this event, a renewed glacial activity is recorded in the high valleys and extends well into the early Holocene. ${ }^{72,77}$ This oscillation precedes the final transition to Holocene interglacial conditions at $11.7 \mathrm{ka}$ cal BP. Palaeoecological data indicate a rapid transformation of forests composition in the valley floors and lower slopes. Here, mixed forest with thermophilous trees such as Quercus, UImus, and Tilia expanded. ${ }^{3}$ Due to the increase of temperature, the timberline rapidly reached an altitude of about $2100 \mathrm{~m}$ a.s.l. within few centuries. ${ }^{57}$ During the Mesolithic, an intense human colonization of the highlands as well as the valley floors and the middle high landscapes of the Alps and the Italian Prealps is documented. ${ }^{78}$ In this context, larger residential sites surrounded by more ephemeral sites could be tied together in seasonal vertical mobility along the treeline belt. ${ }^{58}$

\section{Radiocarbon dating}

The tooth from the hemimandible (Tagliente2) was pretreated at the Department of Human Evolution t the Max Planck Institute for Evolutionary Anthropology (MPI-EVA), Leipzig, Germany, using the method previously published. ${ }^{59}$ Circa 500 mg of the whole root of the tooth is taken. The sample is then decalcified in $0.5 \mathrm{M} \mathrm{HCl}$ at room temperature until no $\mathrm{CO}_{2}$ effervescence is observed. $0.1 \mathrm{M} \mathrm{NaOH}$ is added for 30 minutes to remove humics. The $\mathrm{NaOH}$ step is followed by a final $0.5 \mathrm{M} \mathrm{HCl}$ step for 15 minutes. The resulting solid is gelatinized following Longin $(1971)^{60}$ at $\mathrm{pH} 3$ in a heater block at $75^{\circ} \mathrm{C}$ for $20 \mathrm{~h}$. The gelatine is then filtered in an Eeze-FilterTM (Elkay Laboratory Products (UK)) to remove small $(<80 \mu \mathrm{m})$ particles. The gelatine is then ultrafiltered ${ }^{61}$ with Sartorius "VivaspinTurbo" $30 \mathrm{KDa}$ ultrafilters. Prior to use, the filter is cleaned to remove carbon containing humectants. ${ }^{62,79}$ The samples are lyophilized for 48 hours. The date is corrected for a residual preparation background estimated from ${ }^{14} \mathrm{C}$ free bone samples. These bones were kindly provided by D. Döppes (MAMS, Germany), and one was extracted along with the batch from the tooth. ${ }^{63}$ To assess the preservation of the collagen yield, C:N ratios, together with isotopic values must be evaluated. The C:N ratio should be between 


\section{$\infty$ CellPress}

\section{Current Biology}

2.9 and 3.6 and the collagen yield not less than $1 \%$ of the weight. ${ }^{80}$ For the tooth stable isotopic analysis is evaluated at MPI-EVA, Leipzig (Lab Code R-EVA 1606) using a ThermoFinnigan Flash EA coupled to a Delta V isotope ratio mass spectrometer. The Tagliente tooth passed the collagen evaluation criteria and between 3 and $5 \mathrm{mg}$ of collagen inserted into pre-cleaned tin capsules. This was sent to the Mannheim AMS laboratory (Lab Code MAMS-27188) where it was graphitized and dated. ${ }^{81}$

The age of Tagliente2 is $16980-16510$ years cal BP $\left(95.4 \%\right.$ probability obtained using Reimer et al. $\left.{ }^{16}\right)$. If we compare this result to the one from Tagliente1 (16130-15570cal BP at 95.4\% probability, calibrated using the same curve) it appears that the two calibrated radiocarbon ages differ beyond the $2 \sigma$ level. Therefore, we suggest that Tagliente 1 and Tagliente 2 specimens likely belonged to different individuals. Likewise, stable isotopes of collagen indicate diverse dietary inputs for Tagliente $1^{14}$ and 2 , corroborating the hypothesis of a different origin for these samples. Nevertheless, both age determinations are consistent with an attribution of all the fossils to the first phase of Late Epigravettian occupation at Riparo Tagliente.

\section{DNA Extraction and Sequencing}

The DNA extraction and sample library was prepared in the dedicated ancient DNA laboratory at the Estonian Biocenter, Institute of Genomics, University of Tartu, Tartu, Estonia. The library quantification and sequencing were performed at the Estonian Biocenter Core Laboratory. The main steps of the laboratory work are detailed below.

\section{DNA extraction}

Tooth/bone material was powdered at the aDNA clean lab of the Department of Cultural Heritage, University of Bologna by G.O. and S.S. and sent to the University of Tartu. To approximately $20 \mathrm{mg}$ of powder $1000 \mu \mathrm{l}$ of $0.5 \mathrm{M}$ EDTA pH 8.0 and $25 \mu \mathrm{l}$ of Proteinase K $(18 \mathrm{mg} / \mathrm{ml})$ were added inside a class IIB hood. The sample was incubated for $24 \mathrm{~h}$ on a slow shaker at room temperature. DNA extracts were concentrated to $250 \mu$ using Vivaspin Turbo 15 (Sartorius) concentrators and purified in large volume columns (High Pure Viral Nucleic Acid Large Volume Kit, Roche) using 10X (2.5 ml) of PB buffer (QIAGEN) following the manufacturers' instructions with the only change being a 10 minute incubation at 37 degrees prior to the final elution spin and eluted in $100 \mu \mathrm{L}$ of EB buffer (QIAGEN). Samples were stored at $-20 \mathrm{C}$.

\section{Library preparation}

The extracts were built into double-stranded, single-indexed libraries using the NEBNext DNA Library Prep Master Mix Set for 454 (E6070, New England Biolabs) and Illumina-specific adaptors ${ }^{82}$ following established protocols. ${ }^{82-84}$ DNA was not fragmented and reactions were scaled to half volume, adaptors were made as described in Meyer and Kircher ${ }^{82}$ and used in a final concentration of $2.5 \mathrm{uM}$ each. DNA was purified on MinElute columns (QIAGEN). Libraries were amplified using the following PCR set up: $50 \mu \mathrm{L}$ DNA library, 1XPCR buffer, $2.5 \mathrm{mM} \mathrm{MgCl} 2,1 \mathrm{mg} / \mathrm{ml} \mathrm{BSA}, 0.2 \mu \mathrm{M}$ inPE1.0, 0.2 mM dNTP each, $0.1 \mathrm{U} / \mu \mathrm{l} \mathrm{HGS} \mathrm{Taq} \mathrm{Diamond} \mathrm{and} 0.2 \mu \mathrm{M}$ indexing primer. Cycling conditions were: $5^{\prime}$ at $94 \mathrm{C}$, followed by 18 cycles of 30 s each at $94 \mathrm{C}, 60 \mathrm{C}$, and $68 \mathrm{C}$, with a final extension of 7 minutes at $72 \mathrm{C}$. Amplified products were purified using MinElute columns and eluted in $35 \mu \mathrm{LEB}$ (QIAGEN). Three verification steps were implemented to make sure library preparation was successful and to measure the concentration of dsDNA/sequencing libraries - fluorometric quantitation (Qubit, Thermo Fisher Scientific), parallel capillary electrophoresis (Fragment Analyzer, Advanced Analytical) and qPCR.

Library quality and quantity have been assessed by using Agilent Bioanalyzer 2100 High Sensitivity and Qubit DNA High Sensitivity (Invitrogen). The initial shotgun screening was done on NextSeq500 using the High-Output 75 cycle single-end kit. The secondary, paired-end sequencing was performed on the NovaSeq6000 (Illumina), flowcell S1, without any other samples to ensure no indexhopping due to the single-indexing of the sample, generating 150-bases paired-end reads. Whole genome sequencing with Illumina paired-end (2x150 bp) led to 488 million high-quality reads. About $6.99 \%$ of the reads could be successfully mapped on the human genome sequence with a duplication rate of $51 \%$, leading to an average $0.28 x$ genome coverage (Data S1C). The mapped reads showed nucleotide misincorporation patterns which were indicative of post-mortem damage.

\section{Sequencing filtering, mapping and variant calling analysis}

Before mapping, the paired end reads were merged and corrected using FLASH. ${ }^{85}$ The merged reads were trimmed of adapters, indexes and poly-G tales occurring due to the specifics of the NextSeq500 and NovaSeq technology using cutadapt-1.11. ${ }^{86}$ Sequences shorter than $30 \mathrm{bp}$ were also removed with the same program to avoid random mapping of sequences from other species (Figure S4). The sequences were aligned to the reference sequence GRCh37 (hs37d5) using Burrows-Wheeler Aligner (BWA 0.7.12) ${ }^{87}$ and the command mem with seeding disabled. After alignment, the sequences were converted to BAM format and only sequences that mapped to the human genome were kept with samtools-1.3. ${ }^{88}$ Afterward, the data from different flow cell lanes were merged and duplicates were removed using picard 2.12 (http://broadinstitute.github.io/picard/index.html). Indels were realigned using GATK$3.5^{89}$ and reads with a mapping quality less than 10 were filtered out using samtools-1.3. In order to maximize the coverage of sites included in the 1240 Human Origin capture array, a random read with mapping quality above 30 and phred score above 33 was chosen to represent the pseudo-haploid genotype of our sample, and then merged with reference data from ancient and modern European samples.

aDNA authentication

As a result of degrading over time, aDNA can be distinguished from modern DNA by certain characteristics: short fragments and a high frequency of $\mathrm{C}=>\mathrm{T}$ substitutions at the $5^{\prime}$ ends of sequences due to cytosine deamination. The program mapDamage $2.0^{90}$ was 


\section{Current Biology Report}

used to estimate the frequency of $5^{\prime} \mathrm{C}=>\mathrm{T}$ transitions. Rates of contamination were estimated on mitochondrial DNA by calculating the percentage of non-consensus bases at haplogroup-defining positions as detailed in Jones et al. ${ }^{91}$ Each sample was mapped against the RSRS downloaded from phylotree.org and checked against haplogroup-defining sites for the sample-specific haplogroup.

Samtools $1.9^{88}$ option stats was used to determine the number of final reads, average read length, average coverage etc. (Data S1C).

\section{Calculating genetic sex estimation}

Genetic sex was calculated using the methods described in Skoglund et al., ${ }^{92}$ estimating the fraction of reads mapping to $Y$ chromosome out of all reads mapping to either $X$ or $Y$ chromosome. Additionally, sex was determined using a method described in Fu et al., ${ }^{93}$ calculating the $X$ and $Y$ ratio by the division of the coverage by the autosomal coverage.

\section{Determining mtDNA and Y chromosome haplogroups}

Mitochondrial DNA haplogroups were determined using Haplogrep2 on the command line. ${ }^{94}$ For the determination, the reads were re-aligned to the reference sequence RSRS and the parameter-rsrs were given to estimate the haplogroups using Haplogrep2. Subsequently, the identical results between the individuals were checked visually by aligning mapped reads to the reference sequence using samtools $0.1 .19^{88}$ command tview and confirming the haplogroup assignment in PhyloTree. A total of $5703 \mathrm{Y}$ chromosome haplogroup informative variants ${ }^{25,95}$ from regions that uniquely map to $\mathrm{Y}$ chromosome were covered by at least one read in the sample and these were called as haploid from the BAM file using the-doHaploCall function in ANGSD. ${ }^{96}$ Derived and ancestral allele and haplogroup annotations for each of the called variants were added using BEDTools 2.19.0 ${ }^{97}$ intersect option. Haplogroup assignments of each individual sample were made by determining the haplogroup with the highest proportion of informative positions called in the derived state in the given sample.

\section{Anthropological and virtual analysis of Tagliente2}

The left hemimandible Tagliente2 is mesially broken to the alveolus of the first premolar $\left(P_{3}\right)$, while the ramus is mostly complete, except for the condyle and coronoid process. Four permanent teeth $\left(\mathrm{P}_{4}-\mathrm{M}_{3}\right)$ are still in place into their respective alveoli, but only a tiny apical portion of the $\mathrm{LP}_{3}$ root is preserved (Figure S1). The presence of wear pattern on the third molar (wear stage $2^{98}$ ) and its eruption suggest that the mandible can be ascribed to a young adult, while the robusticity index (42.59, this study) and the gonial angle $\left(110^{\circ}\right)$ fall within the range of male variability. ${ }^{66} \mathrm{X}$-ray microCT scans and digital segmentation of Tagliente2 (Figure 2 ) identified the presence of a rounded alteration close to the buccodistal aspect of the $\mathrm{P}_{4}$ root. The identified lesion shows homogeneous radiopacity surrounded by a radiotransparent thin area (Figure 3 ) and consists of an irregular (Volume $=10.71 \mathrm{~mm}^{3}$; bucco-lingual diameter $=2.48 \mathrm{~cm}$; mesio-distal diameter $=2.90 \mathrm{~cm}$; see Figure 2 ) and compact dental tissue which was mechanically removed and physically analyzed through histological examination (see following section). The latter suggests the presence of stratified and acellular cementum material (Figure 2), which together with anatomical position and morphology (Figure 1B) provides evidence ascribable to focal cemento-osseous dysplasia (FCOD; STAR Methods, Method details), a benign lesion of the bone in which normal bone is replaced by fibrous tissue, followed by calcification with osseous and cementum tissue. ${ }^{99}$

\section{Histopathological examination}

A thin section of $0.005 \mathrm{~mm}$ was sampled for histological analysis. The cross-section has been performed following mesiodistal direction based on the best location for core sampling. The core was fixed in buffered neutral formalin $10 \%$ in order to protect the fibrous elements of cementum from damage caused by the acids used as decalcifying agent performed with Trichloroacetic acid for 7 days. Finally, the section was colored by Hematoxylin / Eosin. The sample was mounted on frosted glass slides and thin-sectioned using a Struers Accutom-50. The preparation of the histological section was carried out at the Centro Odontoiatria e Stomatologia F. Perrini, Pistoia, Italy (STAR Methods, Method details). The section was studied using a Nikon E200 microscope. Photomicrographs were captured using NIS D 3.0 Software and edited in Adobe Photoshop CC.

\section{Removal of Cementoma}

Equipment

- $24 \mathrm{~V}$ dental micro-motor

- $24 \mathrm{~V}$ power supply with a reduction possibility to 18 and $12 \mathrm{~V}$

- Single cell charger

- 5x dental red ring contra angle handpiece

- 1/1 dental blue ring contra angle handpiece

- Dental straight handpiece

- Slotted diamond bur $25 \mathrm{~mm}$ long and $0.5 \mathrm{~mm}$ tip diameter

- Tungsten carbide bur $31 \mathrm{~mm}$ long and $0.8 \mathrm{~mm}$ tip diameter

- Tungsten carbide rosette bur $31 \mathrm{~mm}$ long and $0.8 \mathrm{~mm}$ diameter

- Diamond disc for ceramic $0.35 \mathrm{~mm}$ thick and $20 \mathrm{~mm}$ diameter 


\section{Current Biology}

- Blade $\mathrm{n}^{\circ} 12$ surgical scalpel

- Buck $5 / 6$ periodontal scalpel

- The rotation speed of the $1 / 1$ dental blue ring contra angle handpiece is $40.000 \mathrm{rpm}$, i.e., the motor speed

- The rotation speed of the $5 x$ dental red ring multiplier contra angle handpiece is $200.000 \mathrm{rpm}$. This speed is reduced to about $150.000 \mathrm{rpm}$ when switching to $18 \mathrm{~V}$, and to $100.000 \mathrm{rpm}$ when switching to $12 \mathrm{~V}$

- The rotation speed of the $1 / 1$ dental straight handpiece is $35.000 \mathrm{rpm}$

\section{Procedure}

The procedure consisted of creating an area around the specimen in which a possible introduction of external biological material linked to the extraction procedure was minimized; previously, the specimen had already been widely contaminated and even likely protected with a vinyl glue thin layer. Each operator wore sterile gown, mask, cap and sterile gloves. All the instruments used, including the handpieces, were sterile; the micro-motors have been sanitized and protected by disposable antiseptic sheaths. The specimen was placed on a sterile sheet. The procedure was carried out entirely by working with the aid of a Zeiss $6 x$ binocular microscope.

The aim of the project was the extraction of a bone piece containing a pathological alteration (a probable cementoma) located under the buccal vestibulum, slightly distal to half the root height of the lower left second premolar. The other priority of the procedure was the need to minimize the corruption of the specimen by reducing the operational invasiveness, trying to keep the lingual surface intact, which is the side displayed to museum visitors. Therefore, the difficulty was the extraction of a bone piece limited to the vestibular surface including the lesion and the root portion connected to it without damaging or removing the bone portion and the dental crown above it, also avoiding damaging areas visible to the public.

After a careful tomographic examinations analysis of the exhibit to fully identify the spatial location of the lesion and its relationship with the surrounding bone and dental structures, we moved on to the extraction of the bone piece. The operational phase began with the delimitation of the bone piece by cutting the cortex with a $20 \mathrm{~mm}$ diameter and $0.35 \mathrm{~mm}$ thickness diamond disc mounted on a red ring contra angle handpiece and micro-motor set at $18 \mathrm{~V}(150.000 \mathrm{rpm})$. We pick this thickness because a larger one (0.5) would have been too destructive for the exhibit, while a smaller one (0.2) would have made the bone piece subsequent mobilization more difficult. The slag and debris produced in this surface cutting phase were collected in a sterile tube and labeled as "contaminated external slag." Once the area of about $1 \mathrm{~cm}^{2}$ was delimited, the grooves were deepened with a $25 \mathrm{~mm}$ long and $0.5 \mathrm{~mm}$ diameter conical slotted diamond bur up to a depth of about two thirds of the jaw thickness corresponding to the cortical-spongy bone limit. The pressure exerted with the bur has always been gentle in order to avoid overheating of the bone matrix and loss of diamond crystals. Exploiting the free alveolus of the lower left first molar, as this had been used for previous studies and therefore made removable, it was possible to perform a cut parallel to the lingual surface, orthogonal to the previous perimetral cuts, using a $31 \mathrm{~mm}$ long and $0.8 \mathrm{~mm}$ diameter tungsten carbide bur. The slag recovered at this stage has been collected in a sterile tube, and since it had not been contaminated labeled as "useful for microbiological examination." Given the impossibility to proceed entirely with the diamond tip due to the risk of excessively corrupting the bone matrix, the cuts were defined with a blade $\mathrm{n}^{\circ} 12$ surgical scalpel and a Buck $5 / 6$ periodontal scalpel until complete detachment of the bone piece.

During some separation stages of the internal trabeculation, especially in the periradicular areas, the scalpel blade was gently moved with the aid of small percussions on the handle back, in order to get over the localized resistances that a continuous pressure could not have overcome without significantly increasing strength and dangerously decreasing control. Once all the release incisions were carried out, the bone piece was easily mobilized and extracted with tweezer.

The lesion was therefore exposed by bone matrix abrasion with a $0.8 \mathrm{~mm}$ tungsten carbide rosette bur mounted on a straight handpiece with a $35.000 \mathrm{rpm}$ micro-motor. This progressive controlled abrasion allowed us to reach the exposure of a lesion portion large enough to be easily accessible for histological and DNA examination.

The entire procedure was documented with a Nikon camera with a 105mm Micro-Nikkor lens equipped with annular flash. Genetic analysis of cementoma

We generated $0.28 x$ coverage genome and searched for putatively pathogenic variants in candidate genes (ALPL, CDC73, COL1A1, FOS, FOSB, H3F3B, TP53, ZNF687) known to be involved in in similar pathological conditions to Focal Osseous Dysplasia insurgence or used to perform differential diagnoses, ${ }^{100-104}$ and found a number of missense substitutions which, given the low coverage and ancient DNA degradation are reported here with no further interpretation (Data S1B).

\section{QUANTIFICATION AND STATISTICAL ANALYSIS}

MDS, f3, f4 and qpGraph Reference samples were downloaded from https://reich.hms.harvard.edu/ allen-ancient-dna-resource-aadr-downloadable-genotypes-present-day-and-ancient-dna-data (v42.4) and merged with the newly generated Tagliente2 data. A set of Outgroup $\mathrm{f}^{105}$ in the form $(X, Y$, Mbuti) was run on samples listed in Figure 4A, and the resulting pairwise distance matrix (distance $=1-\mathrm{f3}$ ) was used to compute a Multi-Dimensional Scaling (MDS). The f4 test ${ }^{105}$ was run using the popstats.py script. ${ }^{106}$ qpGraphs were generated using Admixtools, ${ }^{105}$ starting from the backbone described in Fu et al. ${ }^{9}$ and investigating putative positions for Tagliente 2 as informed by the $\mathrm{f} 4$ results described in Figure $4 \mathrm{~B}$. As far as mtDNA analysis is concerned, evolutionary history was inferred by using the Maximum Likelihood method and General Time Reversible model. ${ }^{107}$ The tree with the highest log likelihood (-24501.19) is shown. The percentage of trees in which the associated taxa clustered together is shown next to 


\section{Current Biology}

\section{Report}

the branches. Initial tree(s) for the heuristic search were obtained automatically by applying Neighbor-Join and BioNJ algorithms to a matrix of pairwise distances estimated using the Maximum Composite Likelihood (MCL) approach, and then selecting the topology with superior log likelihood value. A discrete Gamma distribution was used to model evolutionary rate differences among sites $(5$ categories $(+\mathrm{G}$, parameter $=0.0500)$ ). The rate variation model allowed for some sites to be evolutionarily invariable $([+/]$, $49.11 \%$ sites). The tree is drawn to scale, with branch lengths measured in the number of substitutions per site. This analysis involved 39 nucleotide sequences. There were a total of 16578 positions in the final dataset. Evolutionary analyses were conducted in MEGA X. ${ }^{108,109}$ 
Current Biology, Volume 31

Supplemental Information

Early Alpine occupation backdates westward

human migration in Late Glacial Europe

Eugenio Bortolini, Luca Pagani, Gregorio Oxilia, Cosimo Posth, Federica Fontana, Federica Badino, Tina Saupe, Francesco Montinaro, Davide Margaritora, Matteo Romandini, Federico Lugli, Andrea Papini, Marco Boggioni, Nicola Perrini, Antonio Oxilia, Riccardo Aiese Cigliano, Rosa Barcelona, Davide Visentin, Nicolò Fasser, Simona Arrighi, Carla Figus, Giulia Marciani, Sara Silvestrini, Federico Bernardini, Jessica C. Menghi Sartorio, Luca Fiorenza, Jacopo Moggi Cecchi, Claudio Tuniz, Toomas Kivisild, Fernando Gianfrancesco, Marco Peresani, Christiana L. Scheib, Sahra Talamo, Maurizio D'Esposito, and Stefano Benazzi 


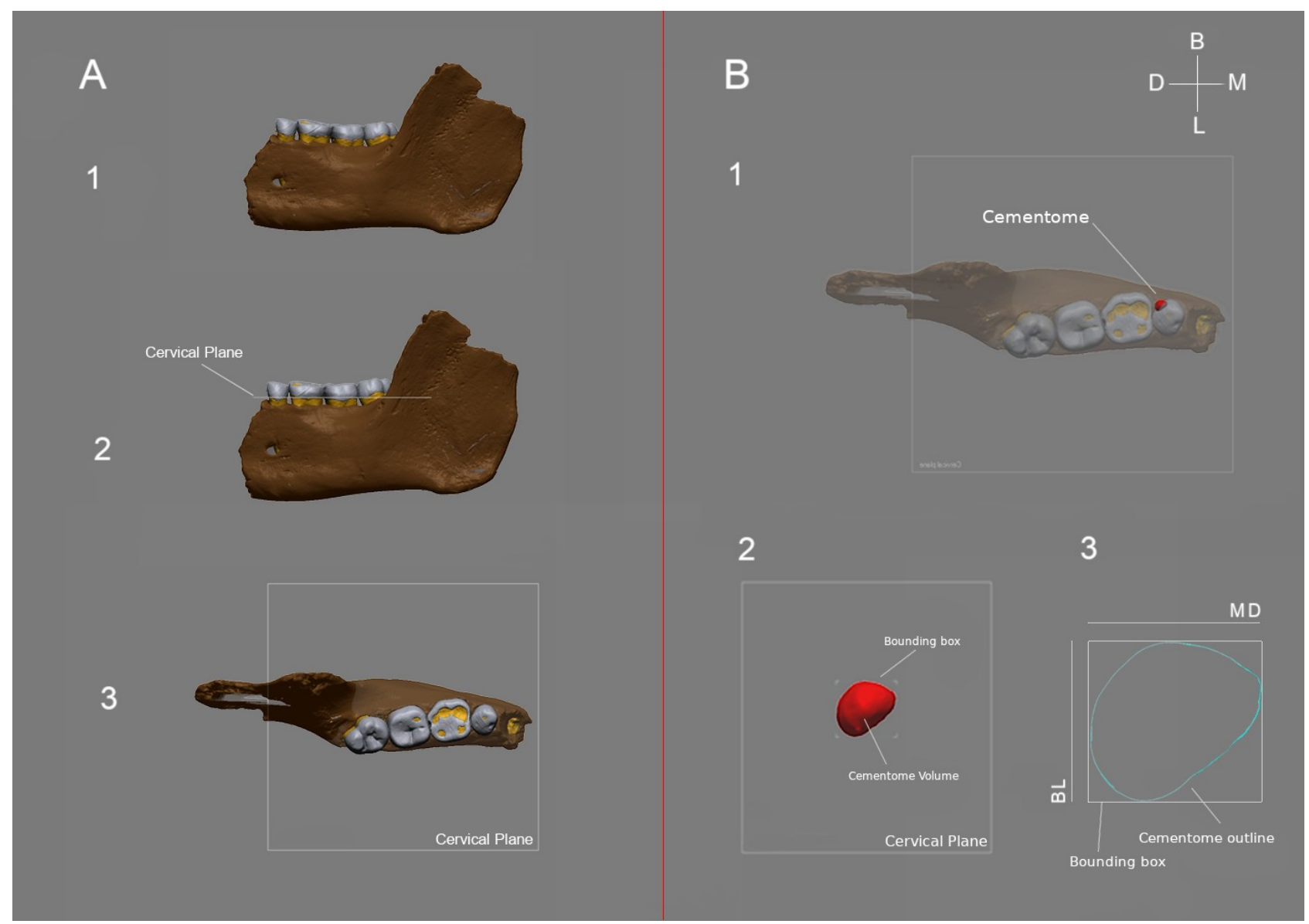

Figure S1. Digital reconstruction of the hemimandible Tagliente2. Related to Figure 1 and Figure 2: Digital reconstruction of the hemimandible. A1) A spline curve was digitized at the cervical line of each crown dentine. A2) A best-fit plane (cervical plane) was obtained. A3) The hemimandible was oriented with the best-fit plane computed at the cervical lines (i.e., the cervical plane that best fits a spline curve digitized at the cervical line), parallel to the $x y$-plane of the Cartesian coordinate system and rotated along the $z$-axis to have its lingual aspect parallel to the $x$-axis. B1) Virtual model oriented in occlusal view. Transparency level set at $72 \%$ to highlight the lesion (in red). B2) Cementome in occlusal view. It was excluded from the context to calculate the Volume and diameters. B3) the outline corresponds to the silhouette of the oriented cementome as seen in occlusal view and projected onto the cervical plane. The contour of the section identified by335 the cervical plane represents the cementome outline. The size of the bounding box enclosing the silhouette was used to collect mesiodistal (MD) and buccolingual (BL) diameters. $M=$ Mesial; $\mathrm{B}=\mathrm{Buccal}$; = D=Distal; $\mathrm{L}=$ Lingual. The hemimandible Tagliente2 was found in 1963 during the first excavation campaigns in the site within disturbed sediments located immediately outside the Riparo Tagliente shelter ${ }^{\mathrm{s}}$. According to excavators such sediments could come from the inner area of the shelter and have been removed during historical excavations in the uppermost deposits which had led to destruction of part of the prehistoric stratigraphic sequence and dumping of sediments outside the shelter entrance. The analysis of seasonality shows an occupation spanning from the beginning of the spring season to the end of autumn ${ }^{\mathrm{S} 2, \mathrm{~s} 3 \text {, }}$ s4, s5. This record consists of dwelling structures, several fireplaces, and some thick soils rich in lithic assemblages, faunal and ochre remains, along with some osseous tools and some beads obtained from marine shells and red deer canines ${ }^{56, s 7, s 8,59}$. An emphasis on processing of the rich lithic, mineral and biological resources offered by the Lessini area is recorded. The variety and abundance of finds indicate an excellent knowledge of the territory surrounding the site, which was intensively exploited at least from the valley-bottom to the top of the plateau ${ }^{\mathrm{s} 2, \mathrm{~S}^{10}}$. Despite this rich record the absence of evidence referring to the time span between 17 and 16 kyrs cal. BP all over the north Italian peninsula does not allow to support any hypothesis on the annual range of mobility of these groups. Nonetheless, the presence of few artefacts and cores manufactured on cherts from the Northern Adriatic Apennines (Umbria-Marche basin) among the wide quantity of items and discarded elements obtained on the local high quality siliceous rocks suggests the persistence of contacts with this area until at least this age ${ }^{\mathrm{s11}}$. Long distance mobility and/or contacts are also supported by marine shells beads from this layers amounting to some hundreds ${ }^{\mathrm{s} 2}$. 


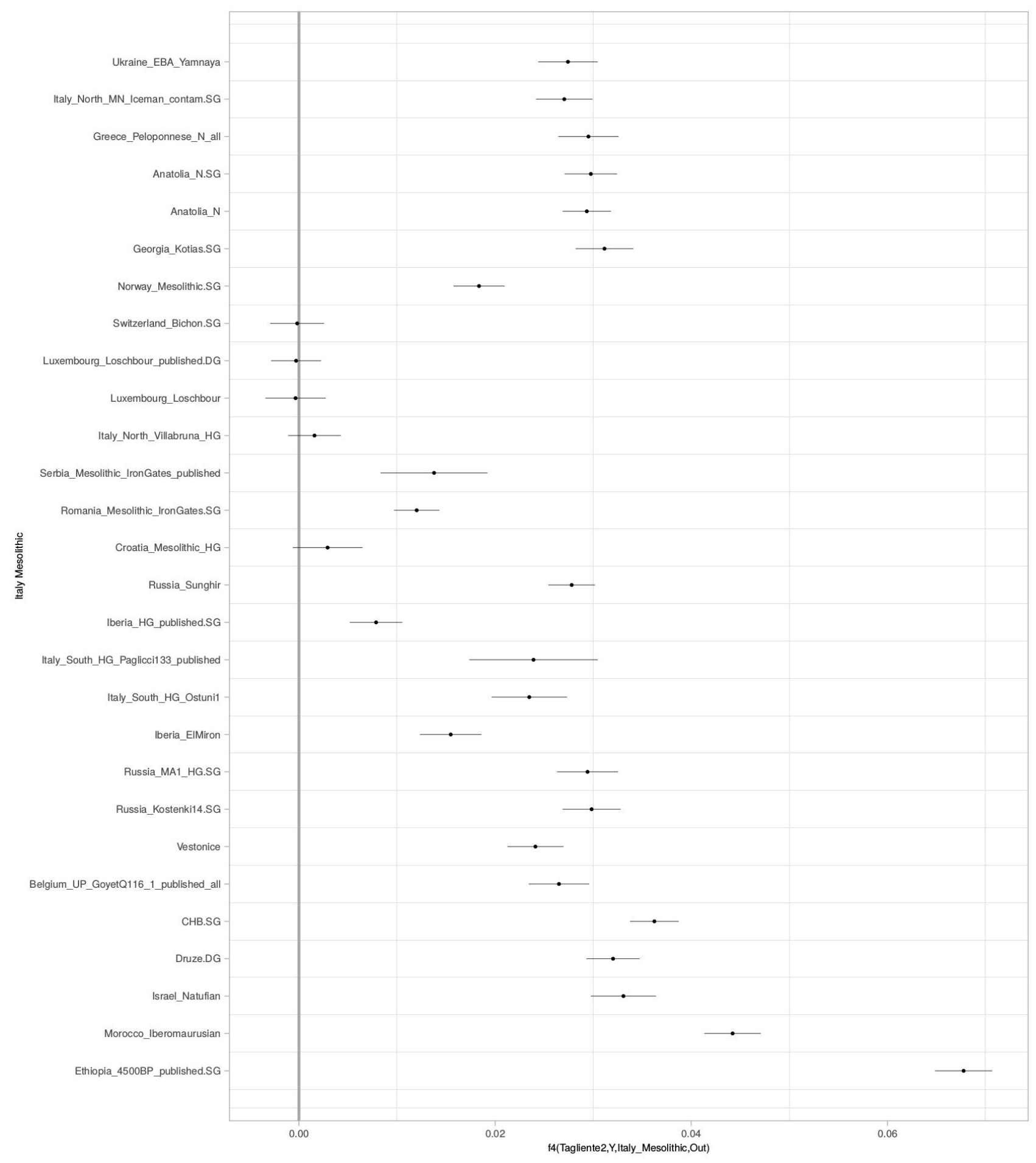

Figure S2. Results of F4 tests. Related to Figure 4: F4 tests in form (Tagliente, X, Mesolitic_Italian_Continenza,Mbuti), where $X$ is one of the populations reported along the $Y$ axis and consistent with Figure $3 \mathrm{~B}$, showing that the available SNPs are sufficient to yield significance in a f4 test. 
A

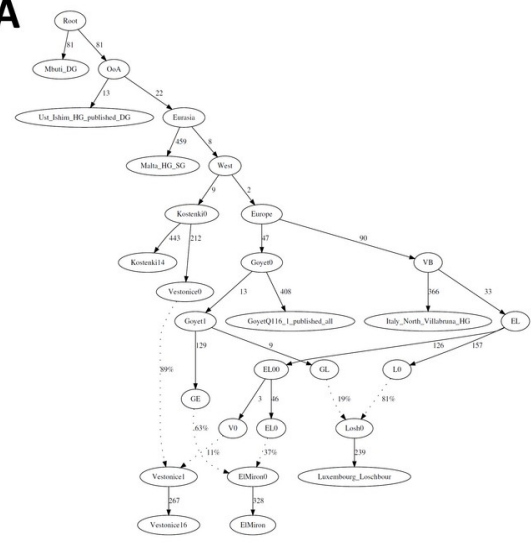

C

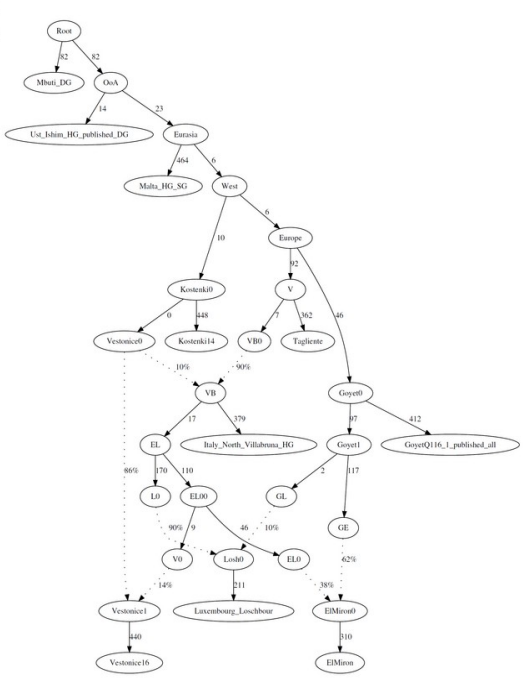

B

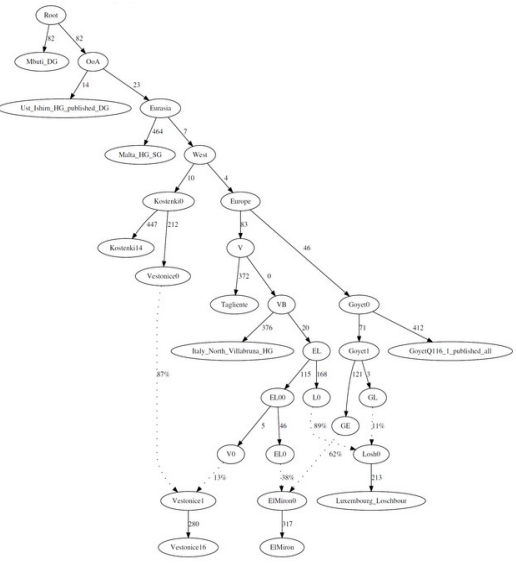

D

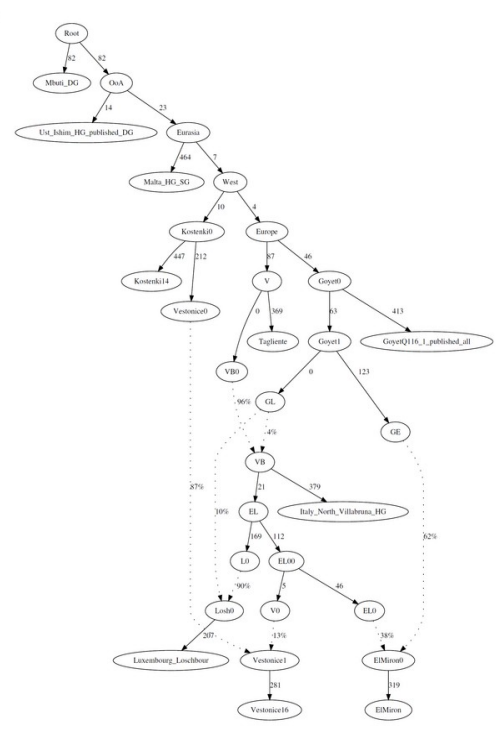

E
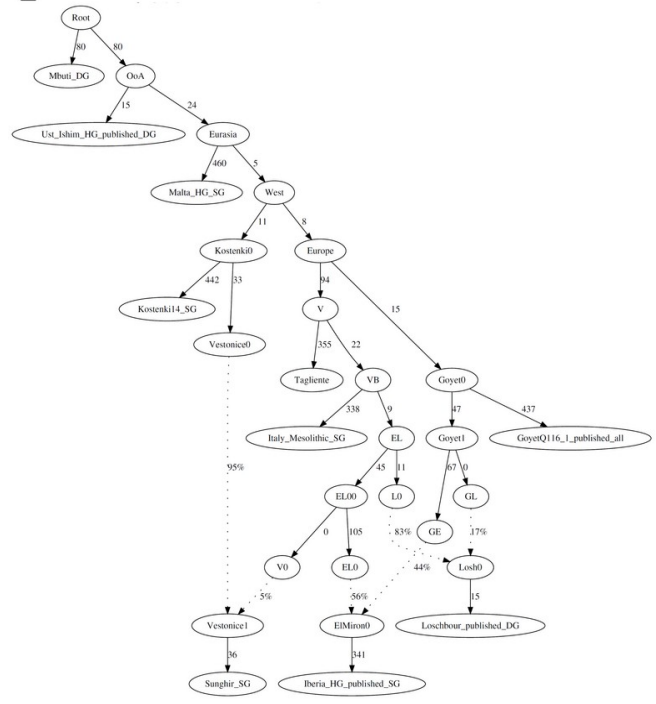

Figure S3. Tagliente2 within the Fu et al. $2016^{\mathrm{S12}}$ qpGraph model. Related to Figure 4. We started from the qpGraph originally proposed in Fu et al. 2016 (Panel A: Final Score 37628.736; dof: 8; no f2 outliers; worst f4: Mbu, Ust,Goy,ItaZ=-3.330) and informed by the $\mathrm{f} 4$ stats shown in Figure 3 placed Tagliente 2 as a basal branch of the Villabruna cluster (Panel B: Final Score 38182.359; dof: 15; no f2 outliers; worst $\mathrm{f4}$ :

Mbu,Ust,Goy, Ita $Z=-3.330$ ). We also explored alternative scenarios featuring Villabruna as an admixture of pre-existing Vestonice (Panel C: Final Score 39471.021; dof: 14; no f2 outliers; worst f4: Mbu,Ust,Goy, Ita Z=3.330) or Goyet (Panel D: Final Score 37245.412; dof: 14; no f2outliers; worst f4: Ust,Ita,Goy,Ita Z=3.503) clusters. Notably, since the number of events and degrees of freedom (dof) are different across different graphs, final scores are not directly comparable. Panel E: to minimize the bias introduced by using capture and shotgun data within the same analysis, we report also the tree proposed as in panel B using, with the exception of Goyet, only shotgun data. Final Score: 34431.549; Degrees of freedom: 15; One f2 outlier: Mal, Sun , Z=2.346; Worst f4: Mbu,Ust,Sun,Goy, Z=3.541 


\section{RIP001.all.hs37d5.sorted.remdup}

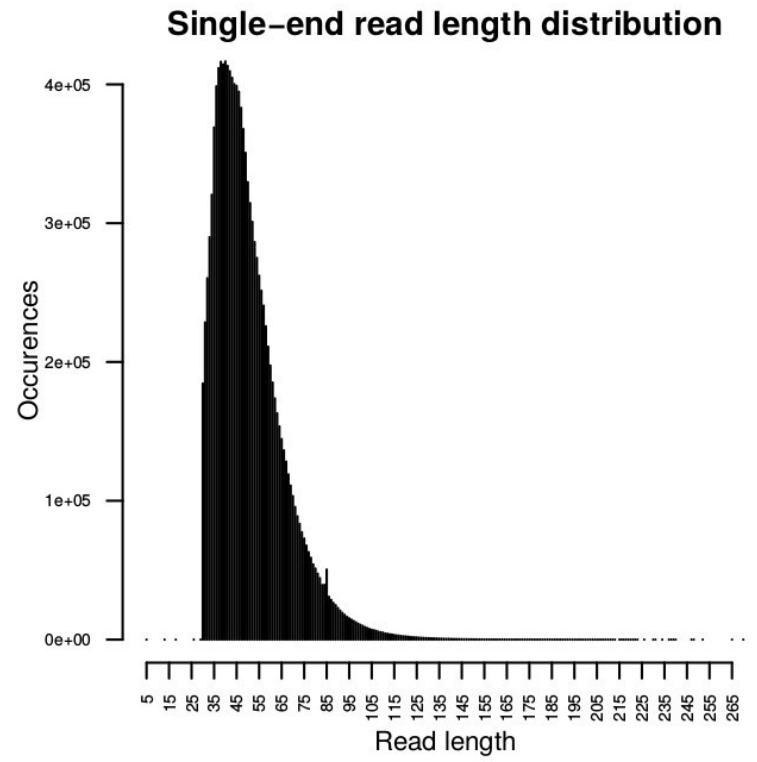

C>T

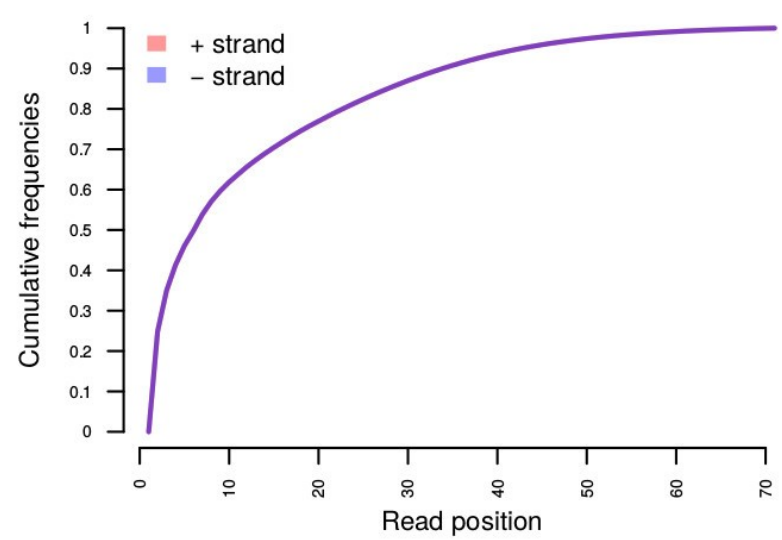

Single-end read length per strand

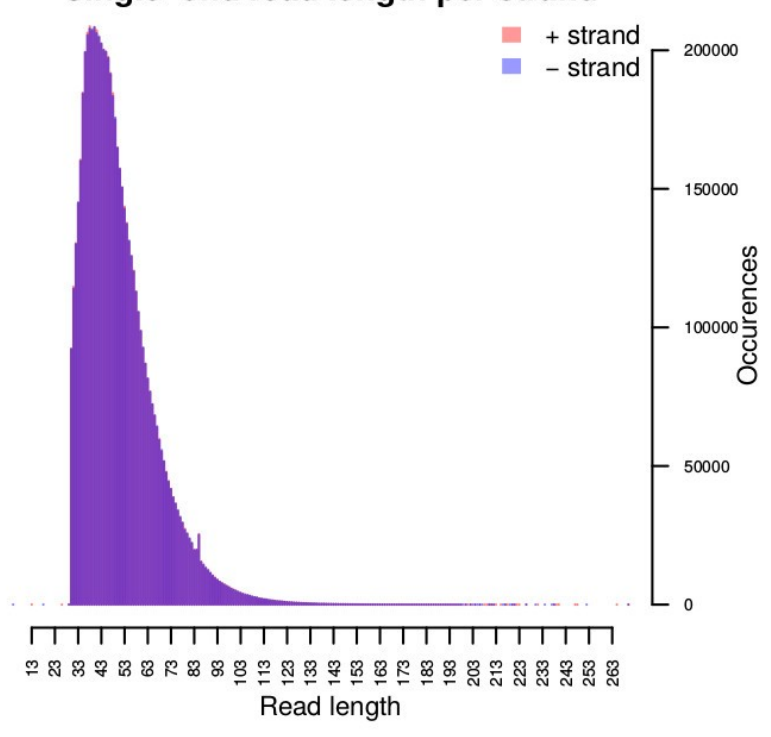

$G>A$

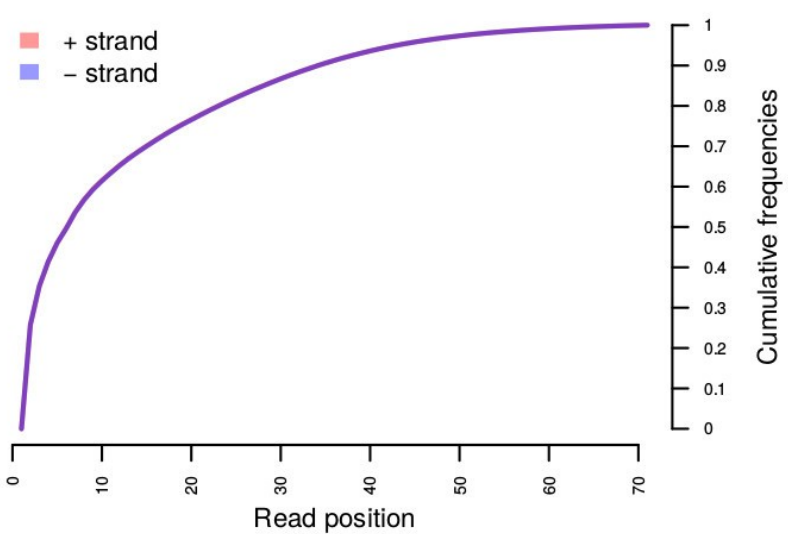

Figure S4. Sequencing read length and substitution rate for Tagliente2 whole genome sequence. Related to Figure 3 and Figure 4 


\section{Supplemental References}

S1. Corrain, C. Un frammento di mandibola umana, rinvenuto a "Riparo Tagliente" in Valpantena (Verona). Atti Dell'Istituto Veneto Sci. Lett. Ed Arti CXXIV, 23-26 (1966).

S2. Fontana, F., Cilli, C., Cremona, M. G., Giacobini, G. \& Gurioli, F. Recent data on the Late Epigravettian occupation at Riparo Tagliente, Monti Lessini (Grezzana, Verona): a multidisciplinary perspective. Preistoria Alp. 44, 51-59 (2009).

S3. Fontana, F. et al. Re-colonising the Southern alpine fringe: diachronic data on the use of sheltered space in the late Epigravettian site of Riparo Tagliente. in Palaeolithic Italy. Advanced studies on early human adaptation in the Apennine Peninsula 287-310 (Sidestone Press, 2018).

S4. Gazzoni, V. et al. Late Upper Palaeolithic human diet: first stable isotope evidence from Riparo Tagliente (Verona, Italy). Bull. Mém. Société Anthropol. Paris 25, 103-117 (2013).

S5. Rocci Ris, A. I macromammiferi di Riparo Tagliente. Archeozoologia e tafonomia dei livelli epigravettiani. (Universita degli Studi di Torino, Dipartimento di Anatomia, Farmacologia e Medicina Legale, 2006).

S6. Bietti, A. et al. Inorganic Raw Materials Economy and Provenance of Chipped Industry in Some Stone Age Sites of Northern and Central Italy. Coll Antropol 14 (2004).

S7. Cavallo, G. et al. Sourcing and processing of ochre during the late upper Palaeolithic at Tagliente rockshelter (NE Italy) based on conventional X-ray powder diffraction analysis. Archaeol. Anthropol. Sci. 9, 763775 (2017).

S8. Cavallo, G. et al. Textural, microstructural, and compositional characteristics of Fe-based geomaterials and Upper Paleolithic ocher in the Lessini Mountains, Northeast Italy: Implications for provenance studies. Geoarchaeology 32, 437-455 (2017).

S9. Peretto, C., Biagi, P., Boschian, G. \& Broglio, A. Living-Floors and Structures From the Lower Paleolithic to the Bronze Age in Italy. Coll. Antropol. 28, 63-88 (2004).

S10. Bertola, S., Broglio, A. \& Cassoli, PF. L'Epigravettiano recente nell'area prealpina e alpina orientale. in L'Italia tra 15.000 e 10.000 anni fa. Cosmopolitismo e regionalità nel Tardoglaciale 39-94 (Museo Fiorentino di Preistoria "Paolo Graziosi", 2007).

S11. Bertola, S., Fontana, F. \& Visentin, D. Lithic raw material circulation and settlement dynamics in the Upper Palaeolithic of the Venetian Prealps (NE Italy). A key-role for palaeoclimatic and landscape changes across the LGM? in Palaeolithic Italy. Advanced Studies on Early Human Adaptations in the Apennine Peninsula 219-246 (Sidestone Press, 2018).

S12. Fu, Q. et al. The genetic history of Ice Age Europe. Nature 534, 200-205 (2016). 